\title{
Dative for accusative case interchange in epistolary formulas in Greek papyrus letters
}

\author{
Joanne Vera Stolk \\ Department of Philosophy, Classics, History of Arts and Ideas, University of Oslo, Norway \\ Delphine Nachtergaele
}

Department of Ancient Greek Linguistics, Ghent University, Belgium

\begin{abstract}
Greek papyrus letters preserve not only instances of the replacement of the dative case; they also show the use of the dative instead of the accusative case as direct object and disjoint infinitival subject. This

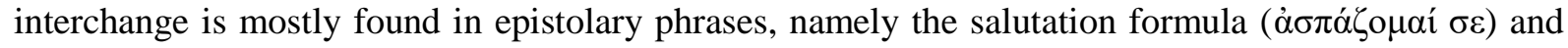

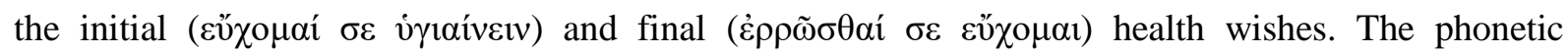
similarity of the pronouns might have created the circumstances for case confusion. Contamination of the constructions reflects the difficulties of the scribes to construct conservative epistolary phrases and, thereby, diachronic phraseological variation might reflect language change. In salutation formulas, the use of a dative Addressee could be explained by analogical overextension from the category of communication verbs taking a dative complement. The decline of the accusative and infinitive construction might be one of the reasons why the accusative disjoint infinitival subject is replaced by the dative case in health wishes.
\end{abstract}

Keywords Greek papyrology, Greek linguistics, epistolary formulas, case interchange, language change, private letters

\section{Introduction}

The loss of dative case morphology is an important change in the case system of postClassical Greek. The functions of the former dative case are taken over by the bare genitive and accusative cases and by prepositional phrases (Horrocks 2007: 628-629; Brixhe 2010: 239-240; Holton and Manolessou 2010: 546-547). The corpus of Greek papyri from Egypt (300 BC $-800 \mathrm{CE}$ ) provides an important source for the history of the Greek language. Examples of the replacement of the dative by the genitive and accusative cases are attested in papyri and ostraca from the Roman and Byzantine periods (Humbert 1930; Stolk 2015). Interestingly, during this period of dative case merger, the papyri also preserve examples of the use of a dative instead of the expected accusative case. The attestations of dative for accusative interchange are relatively frequent and might even outnumber the examples of accusative for dative interchange, seemingly contradicting the expectations of the process of dative case syncretism described above. How can this be explained? In which contexts are these examples of dative for accusative interchange found? And what might have caused them? Those are the questions we intend to address in this article.

The instances of dative for accusative interchange have not yet been studied in depth. In his study of the disappearance of the dative case, Humbert (1930: 178-181) only discussed the examples of the replacement of the dative by the accusative case in the papyri. Kapsomenakis (1938: 24n.2) mentions some additional examples of accusative by dative replacement for the first and second person singular. He explains these examples as follows: 
"aus der Tatsache, daß der Dativ in dieser Zeit vielfach durch den Akk. ersetzt wurde, ist eine Unsicherheit entstanden, so daß die Schreiber nicht mehr wußten, ob sie den Dativ oder den Akk. anwenden sollten."

In other words, the use of the dative instead of an accusative can be understood as a secondary result of the process of dative case syncretism. Functional syncretism is often preceded by a period of synchronic variation and alternation in which both forms are interchangeably employed (Barðdal \& Kulikov 2009: 470). ${ }^{1}$ Even after merger of the case forms in the spoken language, hypercorrection can occur "when a speaker deliberately tries to adjust his or her own speech in the direction of another variety perceived as more prestigious but 'overshoots the mark' by applying an adjustment too broadly" (McColl Millar 2015: 104). Why do scribes in the papyri use the dative case in constructions in which the accusative used to be more common? Is the interchange limited to a certain context? Which factors may have influenced scribal variation?

A relevant clue about the context of this particular confusion of cases is provided by Mandilaras (1973: 358). He observed that dative-accusative alternation with participles is especially found in formulaic expressions in letters (see also James 2007: 162n.369). Exler (1923: 76) provides an example of the variation between dative and accusative in his study of epistolary formulas (1). ${ }^{2}$

\section{P.Oxy. IX 1220, 26-27 (Oxyrhynchites, III CE) ${ }^{3}$}

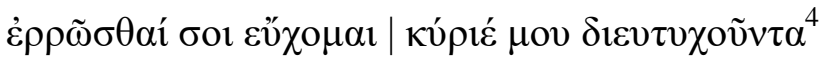

'I pray that you to be healthy, my lord, and have continuous prosperity'

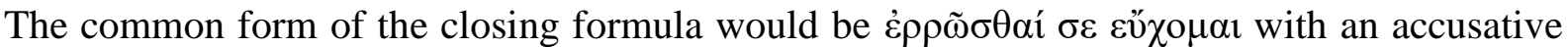
pronoun $(\sigma \varepsilon)$ instead of the dative ( $\sigma \circ \imath)$. The participle $\delta 1 \varepsilon v \tau v \chi 0 \tilde{v} \tau \alpha$ which is governed by the pronoun is still written in the accusative case, consistent with the common formulation of the phrase. Due to the conservative nature of formulaic phrases, the grammar of fixed expressions can become increasingly irregular with respect to the actual spoken language (Wray 2009: 3233). Epistolary formulas were modelled on existing fixed phrases rather than being ad hoc formations which may have been subject to the on-going changes in the grammar of the language of the writer. Hence, a study of variation and change in formulaic language may not just reveal changes in the language, but also "the extent to which a writer was familiar with the conventions and fashions of formal letter - writing of that period" (Elspass 2012: 164).

\footnotetext{
${ }^{1}$ Comparable to the stage of ambiguity in grammaticalization processes, see e.g. Heine 2003: 579.

${ }^{2}$ Yet, previous studies of papyrus letters (Ziemann 1910; Exler 1923; Zilliacus 1943; Koskenniemi 1956; White 1986) did not discuss this kind of variation. Salonius (1927: 22) only referred to the accusative for dative interchange.

${ }^{3}$ Papyrus editions are cited according to the Checklist of Greek, Latin, Demotic and Coptic Papyri, Ostraca and Tablets, edited by John F. Oates, Roger S. Bagnall, Sarah J. Clackson, Alexandra A. O'Brien, Joshua D. Sosin, Terry G. Wilfong, and Klaas A. Worp, http://scriptorium.lib.duke.edu/papyrus/texts/clist.html, January, 2015. The Greek text is based on the Papyrological Navigator (PN; www.papyri.info) and checked against the editio princeps and BL (Berichtigungsliste der griechischen Papyrusurkunden aus Ägypten, Leiden: Brill); metadata are taken from Trismegistos and HGV (both accessible through the PN); translations of the Greek text are our own, but may be based on the edition if available.

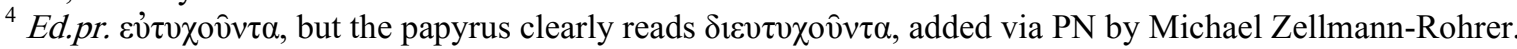


Therefore, we will also compare the variation in epistolary phrases to similar constructions outside of fixed phrases and results from other studies on the history of the Greek language.

First and foremost, our goal is to explain case variation in the written language of the papyri rather than to reconstruct the process of dative case syncretism in the contemporary spoken language. Therefore, we will provide a quantitative overview of all instances of case interchange (2), followed by a detailed examination of the phonetic, phraseological, semantic and syntactic properties of the examples in question (3). Our study is not limited to Greek produced by well-educated monolingual scribes and there may be various factors governing the variation in documentary papyri. Hence, our linguistic approach is always combined with the qualitative analysis of the linguistic and social context of the individual attestations.

\section{Data}

The empirical basis of this article is formed by three separate collections of data, all of them ultimately based on the corpus of published Greek papyri and ostraca in the Papyrological Navigator $(\mathrm{PN})^{5}$. The first set of data was collected by means of the database Trismegistos Text irregularities (Depauw and Stolk 2015). ${ }^{6}$ Many of the instances of dative replacement in the papyri are found with personal pronouns (Humbert 1930: 166) and, therefore, we focussed in particular on pronominal case regularizations made by the editor of the text. ${ }^{7}$ In order to examine Mandilaras' observation that dative-accusative interchange is especially common in formulaic expressions in letters (cf. supra), information for the epistolary formulas will be supported by another database, i.e. the database of 'Greek private letters on papyrus and ostracon (BC 300-AD 800),' also composed within the Trismegistos portal. These texts have been manually identified as private letters and tagged for various epistolary formulas by the second author of this article. Finally, in order to allow for comparison of the constructions of the epistolary formulas with general language use in private letters, the data was complemented by a collection of all second person singular pronouns in the dative and the accusative case in papyri tagged as 'Brief (privat)' in the HGV metadata of the PN, analysed by the first author of this article. Below, we discuss the results of the quantitative analysis.

\subsection{Personal pronouns}

All pronominal dative for accusative case interchanges date between the I-II and the VI centuries CE. Case interchange is found for first and second person, singular and plural

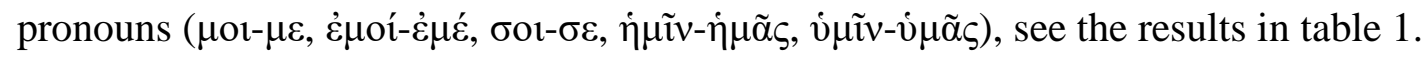

Table 1: dative for accusative with first and second person pronouns ${ }^{8}$

\footnotetext{
${ }^{5}$ www.papyri.info

${ }_{7}^{6}$ www.trismegistos.org/textirregularities

${ }^{7}$ Full noun phrase addressees are occasionally denoted in the nominative, genitive and dative instead of the expected accusative case. The use of different cases for several consecutive addressees is common as well (Brixhe 2010), cf. discussion in 3.1.

${ }^{8}$ Based on editorial regularizations of the dative into the accusative first and second person singular (irregular

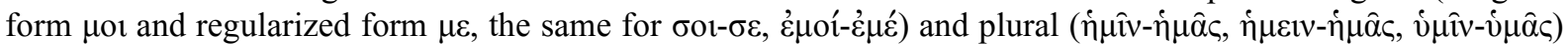
in TM Text Irregularities, state February 2015. Case interchange is also attested for the third person pronouns,

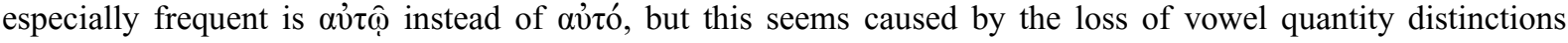
(Gignac 1976: 275-277). Uncertain results were left out; some extra examples were added because they were
} 


\begin{tabular}{|l|l|l|l|}
\hline Personal pronoun & $1 \mathrm{sg}$ & $2 \mathrm{sg}$ & $12 \mathrm{pl}$ \\
\hline $\mathrm{N}$ texts with dat. for acc. pronoun & 30 & 52 & 6 \\
\hline $\mathrm{N}$ texts PN with pronoun & 9162 & 7914 & 4274 \\
\hline $\mathrm{Nf}$ p/1000 texts & 3,3 & 6,6 & 1,4 \\
\hline
\end{tabular}

However, the editorial case regularizations are far more common for the singular pronouns, especially the second person singular pronoun. ${ }^{9}$

\subsection{Private letters}

If the interchange of dative for accusative is especially frequent in epistolary formulas (see Mandilaras' observation, supra), it is expected to show up more often in texts that use this type of formulas. From the results of the case interchanges noted by editors, it can be observed that the use of a dative pronoun instead of an accusative pronoun is indeed more common in (private) letters. In total, 55 of the 83 texts with this interchange are described as a 'Brief' or 'Brief (privat)' in the HGV metadata of the PN, see table 2. ${ }^{10}$

Table 2: dative for accusative in (private) letters in comparison to other genres of papyri ${ }^{11}$

\begin{tabular}{|l|l|l|l|}
\hline Text type & Private letter & Letter & Other \\
\hline $\mathrm{N}$ texts with dat. for acc. pronoun(s) & 44 & 11 & 28 \\
\hline $\mathrm{N}$ texts PN & 3424 & 3379 & 45366 \\
\hline $\mathrm{Nf}$ p/1000 texts & 12,9 & 3,3 & 0,6 \\
\hline
\end{tabular}

It has to be noted that the texts in the category 'other' could still contain epistolary phrases, even though they are not primarily characterized as letters. ${ }^{12}$

\subsection{Epistolary formulas}

The attestations of accusative by dative replacement with the second person singular pronoun in private letters could be caused by the predominant occurrence of interchange in specific epistolary formulas. And indeed, in the 52 letters with editorial regularizations of a dative second person singular pronoun back into an accusative case (table 1), 26 interchanges

missing in the database due to annotation mistakes (these will be corrected later): P.Abinn. 31, 4; P.Mich. III 206, 3 and 21; P.Oxy. LVI 3859. The normalized frequency is based the number of texts in PN containing a

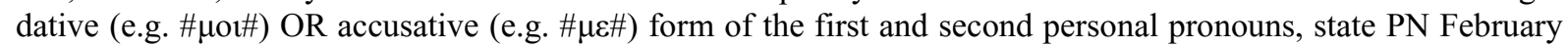
2015.

9 The differences here expressed by the normalized frequency are significant (Chi-square $=20,6793$ with 2 degrees of freedom and $p=3,233 \mathrm{e}-05$ ). However, the effect size is very small (Cramer's $\mathrm{V}=0,03$ ) due to the frequent occurrence of personal pronouns in papyri.

${ }^{10}$ The results are significant (Chi-square $=302,2633$ with 2 degrees of freedom and $p<2.2 \mathrm{e}-16$. However, the effect size is very small (Cramer's $\mathrm{V}=0,08$ ) due to the high frequency of correctly used pronouns in the papyri.

${ }^{11}$ Based on editorial regularizations of the dative into the accusative first and second person singular and plural, cf. n. 8. The total is based on a search in Greek texts with transcription, compared to those with metadata "Brief" and of them "Brief (privat)", state PN February 2015.

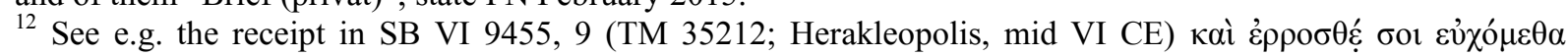
$\pi \mathrm{o} \lambda \lambda$ oî $\chi \rho o ́ v[\mathrm{orc}]$ (reading BL 12, 197). 
occurred in salutations (e.g. $\dot{\alpha} \sigma \pi \alpha ́ \zeta o \mu \alpha i ́$ $\sigma \varepsilon$ 'I greet you') and an equal number in health wishes

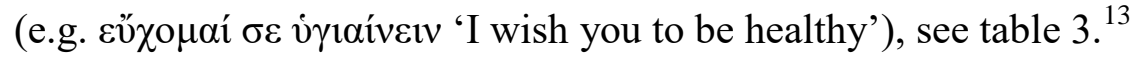

Table 3: formulas with dative for accusative in private letters

\begin{tabular}{|l|l|l|l|}
\hline Formula & Salutation & Initial health wish & Closing formula \\
\hline $\mathrm{N}$ texts dat. for acc. $2 \mathrm{sg}$ & 26 & 10 & 16 \\
\hline $\mathrm{N}$ texts with formula with 2sg & 394 & 260 & 909 \\
\hline $\mathrm{Nf}$ p/100 texts & 6,6 & 3,8 & 1,8 \\
\hline
\end{tabular}

If we compare these results with the corpus of epistolary formulas from the database of private letters, it turns out that the number of private letters with a dative for accusative pronoun in the greeting formula and/or the health wish is indeed very high (resp. almost 7 and 4 out of a 100 texts) in comparison with the general occurrence of case interchange found with the second person singular in the papyri (ca. 7 out of a 1000 texts with the pronoun, see table 1). In other words, case interchange is clearly very frequent in salutations (in particular

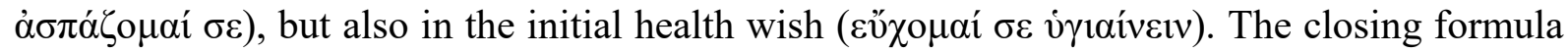

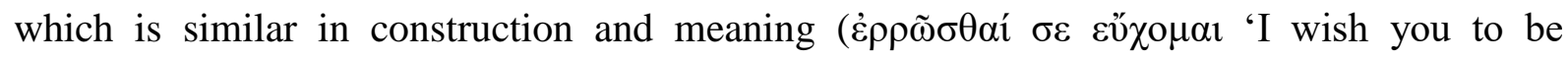
healthy') is even more frequently attested, but case interchange does not seem as common as in the initial health wish. ${ }^{14}$ Possible explanations for this distribution will be discussed in the following sections.

\section{Analysis}

Most likely, all interchanges are ultimately caused by a lack of knowledge or attention to the norms of the written language, but this is not the main point of this study. We want to explore the results of this process in more detail. Variation and change in the language of papyri and ostraca can have multiple causes, including language internal and external motivations (Leiwo 2012). The main agents of variation found in written sources are the scribes (Wagner et al. 2013). ${ }^{15}$ Therefore, the analysis of the variation between dative and accusative cases in epistolary phrases will focus on the possible reasons for a scribe to alternate between these cases. ${ }^{16}$ The motivation for the interchange of $\sigma 01$ for $\sigma \varepsilon$ could lie at various levels of language organization (cf. Halla-aho 2010). It might be related to changes in the pronunciation and difficulties with spelling of the two vowels (Humbert 1930: 167-168, 178), but also to the meaning of the predicate governing the pronouns and/or the syntax of the constructions in which they occur. The context also plays a role: perhaps the scribe copied the spelling of the pronoun analogically from an adjacent construction or he might have confused variant formulations of formulaic phrases with a similar meaning (cf. Vierros 2012). Of

\footnotetext{
${ }^{13}$ Further, in two greetings the plural $\mathfrak{v} \mu \hat{i} v$ appears instead of $\mathfrak{v} \mu \hat{\alpha} \varsigma$. For practical reasons, these occurrences are not included in table 3 , but will be discussed in section 3.1 .

${ }^{14}$ The distribution is significant (Chi-square $=17,7478$ with 2 degrees of freedom and $p=0,00014$ ), although the effect size is still small (Cramer's $\mathrm{V}=0,11$ ).

${ }^{15}$ We understand a 'scribe' to be any writer of a text, not necessarily a person with writing as a profession, see also Wagner et al. 2013: 3-4.

${ }^{16}$ Individual differences between scribes may be substantial, cf. e.g. the variation in orthography, morphology and syntax of scribes writing ostraca in the Eastern desert, as sketched by Bülow-Jacobsen (2001) and Leiwo (2005).
} 
course, the sociolinguistic context, such as the level of education and native language of the scribe, is relevant as well, although it would not suffice merely to refer to 'Greek incompetence' to explain this specific interchange of case forms (Evans 2012). By examining various possible factors, we attempt to explain why it is exactly the dative $\sigma o t$ that is found so often instead of the standard accusative pronoun $\sigma \varepsilon$ and why this phenomenon occurs especially in these epistolary phrases.

\subsection{Salutation ${ }^{17}$}

In this section, we discuss the possible motivations for the interchange of dative for accusative in salutation formulas, such as the phonetic similarity of the endings of the dative and accusative pronouns (3.1.1), the influence of variant formulations of salutation phrases (3.1.2) and the functional similarity of the two cases to express the Addressee of greeting (3.1.3).

\subsubsection{Phonetic similarity and scribal context}

Humbert (1930: 167) explained the confusion of the dative ( $\mu \mathrm{ol}, \sigma o 1)$ and accusative $(\mu \varepsilon, \sigma \varepsilon)$ singular pronouns phonetically (see also Salonius 1927: 35; Kapsomenakis 1938: 24n2):

“L'ancienne diphtongue finale de $\mu$ oí et de ooí s'est réduite, par les effects de l'itacisme, à un $i$ dont nous ignorons le timbre. Or il suffit que cet $i$ soit prononcé d'une certain façon pour que si soit peu discernable de l'accusatif $\sigma \dot{\varepsilon} . "$

However, based on the relative infrequency of the interchanges of $\langle 01\rangle$ and $\langle\varepsilon\rangle$, Gignac (1976: 274n.1) concluded that the interchange of dative and accusative in the first and second person pronouns "is probably mainly the result of syntactical confusion of cases". But syntactic confusion does not explain why dative-accusative interchange seems to be more common for the singular pronouns than for plural pronouns and nominal forms. Compare the letter from Tasoucharion to her brother Neilos. The first part of this letter deals with business, while the last section contains salutations from herself and her social circle to her brother and his social circle (2).

\footnotetext{
${ }^{17}$ The attestations of the dative instead of the accusative second person singular pronoun (cf. table 3 ) are found in the following 26 texts: O.Claud. I 143, 10 (TM 24155; Mons Claudianus, ca. 100-120 CE); P.Mich. VIII 482, 10 (TM 17241; Karanis, 23.08.133 CE); P.Mich. III 206, 21 (TM 28795; Egypt, ca. late II CE); P.Mich. III 209, 18 (TM 28798; Karanis, ca. late II CE); P.Harr. I 103, 12 (TM 28709; Oxyrhynchites, II CE); P.Gron. 19A, 16 (TM 29212; Egypt, II CE); O.Claud. II 279, 15 (TM 29696; Mons Claudianus, II CE); BGU II 601, 21 (TM 28189; Alexandria, II CE); P.Dura 46, 2 (TM 30498; Syria, early III CE); P.Oxy. LXII 4340, 29, 30 (TM 31664; Oxyrhynchos, ca. late III CE); P.Giss.Univ. III 26, 14 (TM 31818; Egypt, III CE); SB V 8002, 27 (TM 30792; Egypt, III CE); P.Oxy. XXXI 2599 (i), 27 (TM 30439; Oxyrhynchites, III-IV CE); P.Oxy. XXXI 2599 (ii), 36 (TM 30439; Oxyrhynchites, III-IV CE); SB XVIII 13593, 4 (TM 30995; Egypt, III-IV CE); P.Lond. VI 1918, 3 (TM 16856; Phathor, ca. 330-340 CE); P.Neph. 12, 5 (TM 33565; Omboi, 350-370); P.Herm. 13, 13 (TM 33471; Egypt, IV CE); P.Köln V 239, 3, 8 (TM 33497; Egypt, IV CE); PSI III 212, 3 (TM 33231; Oxyrhynchos, IV? CE); P.Oxy. X 1299, 4, 12, 13 (2x) (TM 33637; Oxyrhynchos, IV CE); O.Wilck. 1219, 4 (Trismegistos 77619; Elephantine, I-IV CE); P.Mich. VIII 519, 4 (TM 32728; Karanis, IV-V CE); P.Oxy. LVI 3864, 35 (TM 35475; Oxyrhynchos, V CE); P.Batav. 21, 17 (TM 37506; Oxyrhynchos, V CE); SB XIV 11492, 14 (TM 36254; Egypt, VI CE). Another example may be found in an unpublished papyrus letter from the Collection of the Oslo University Library, inv. 485, 11. 20 and 23 (Egypt, II-III CE). Two further interchanges are found with the second person plural pronoun: SB XII 10840, 17 (TM 32557; Egypt, IV CE); P.Oxy. LVI 3859, 50 (TM 33600; Oxyrhynchos, IV CE). Another possible attestation of i $\mu \mathrm{i} v$ instead of i $\mu \hat{\alpha} \varsigma$ is found in CPR XIV 51, 11 (TM 37206; Egypt, VI CE), but as part of the epistolary phrase is supplemented, it is left out of the discussion here:

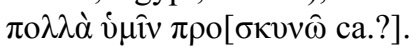


(2) BGU II 601, 19-26 (Alexandria, II CE)

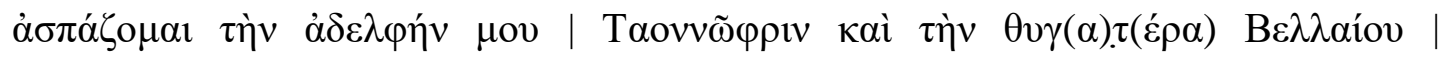

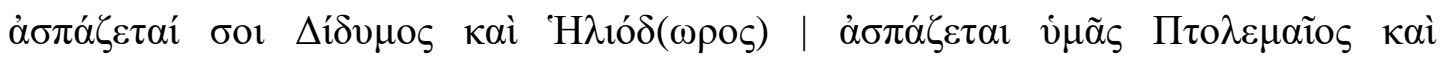

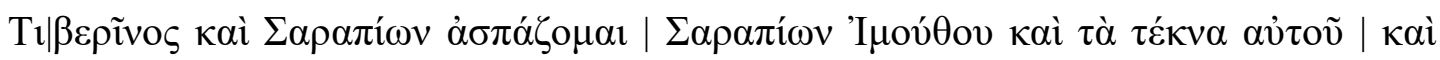

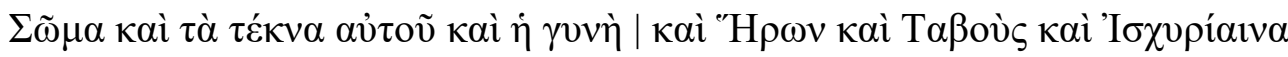

'I greet my sister Taonnophris and the daughter of Bellaios. Didymos and Heliodoros greet you. Ptolemaios and Tiberinos and Sarapion greet you. I greet Sarapion son of Imouthes and his children and Somas and his children and his wife and Heron and Tabous and Ischyriaina.

Since the letters from Tasoucharion to her brother are in different hands (BGU II 601-602; BGU III 714, 801; P. Giss. I 97), they were probably written for her by various scribes. The greetings in this letter are standard, apart from the occasional case interchanges. Personal names are usually in the expected accusative (as Addressee of $\dot{\alpha} \sigma \pi \alpha ́ \zeta o \mu \alpha \imath$ ) and nominative (as subject of $\dot{\alpha} \sigma \pi \alpha \dot{\zeta} \varepsilon \tau \alpha \imath)$ cases respectively. Especially at the end of a salutation, the scribe has a tendency to resort to the nominative ending instead of an accusative to express the object (cf.

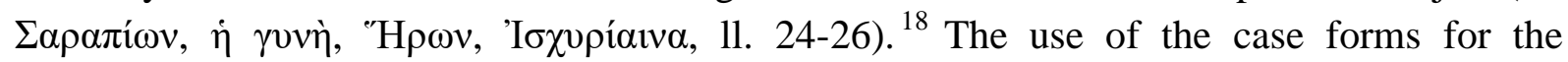
pronouns reflects a different distribution of cases: the singular pronoun is in the dative case

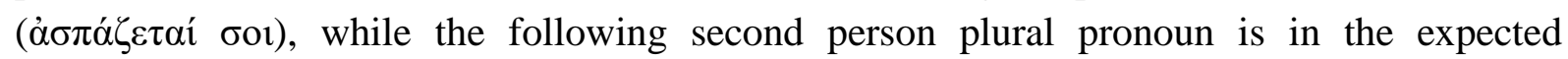
accusative case ( $\dot{\alpha} \sigma \pi \hat{\alpha} \zeta \varepsilon \tau \alpha \imath \dot{v} \mu \tilde{\alpha} \varsigma)$. This might be because the dative and accusative singular clitic pronouns $(\sigma 0 \mathrm{l}-\sigma \varepsilon)$ were closer in pronunciation than the case endings of the plural forms

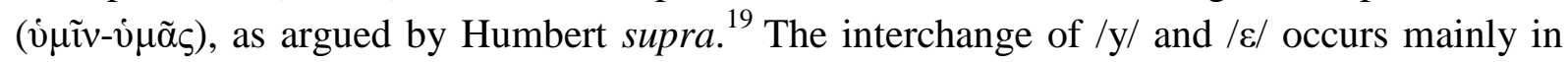
unaccented syllables, possibly reflecting a reduction of unstressed vowels to /ə/ (Gignac 1976: 275). Therefore, the difference in pronunciation between the unstressed vowels in the case ending of a clitic pronoun might have been very small (Gignac 1976: 273-275). In these circumstances, the occurrence of the pronoun before a word starting in a vowel could further obscure the precise pronunciation of the vowel (3).

(3) PSI III 212, 3-4 (Oxyrhynchos, IV? CE)

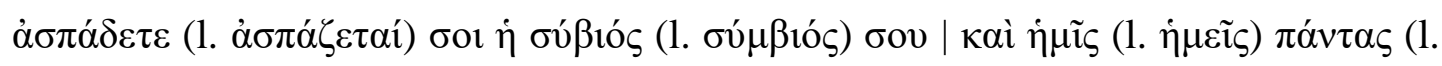

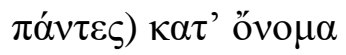

'Your wife greets you, and we all (do), by name.'

\footnotetext{
${ }^{18}$ The nominative of personal names could be used as an "invariant form" (Adams 2013: 206-212). However, not only personal names are involved here. A switch from accusative to nominative in a list of items could be understandable, as the nominative may be "a natural 'default' in a list" (Evans 2012: 32). The same principle might play a role in the long lists of greetings, especially when greetings from the sender to third parties (accusative) and from the third parties (nominative) to the addressee are mixed, as is the case here.

${ }^{19}$ The various spellings ( $\left.\dot{v} \mu \hat{\imath} v, \dot{v} \mu \hat{\eta} \varsigma, \dot{v} \mu \hat{\alpha} \varsigma\right)$ of the plural pronoun in SB XII 10840, 17-20 (Egypt, IV CE) might reflect an uncertainty about the spelling and morphology of the plural case endings as well. The addressee of the greeting is generally in the accusative case and the deviations are merely phonetic in this letter, e.g. $\dot{\alpha} \sigma \pi \alpha \alpha^{\prime} \mid \delta \omega \mu \alpha$

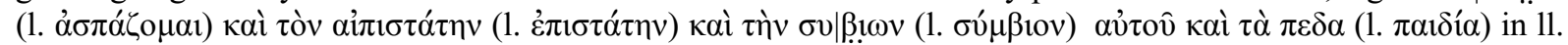
20-22.
} 
Only the last part of this letter is preserved, but in the salutation formula almost every word is written with a non-standard orthography. Most of them involve phonetic spellings, e.g.

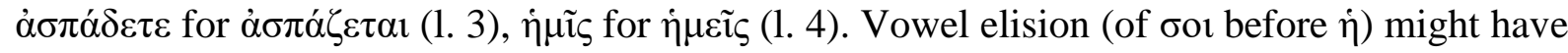
played a role in a phonetically written letter like this one, but the majority of the interchanged dative singular pronouns is not followed by a vowel, see e.g. (2).

Still, it is likely that phonetic factors could have enhanced the confusion of the vowels. If it was difficult to hear the difference between the vowel endings, the scribe would have to determine himself how to write the case form. In the majority of the letters, the accusative pronoun is found in these salutation formulas due to the scribe's knowledge of the norms of the written language. The most likely alternatives are any of the attested case endings of the personal pronoun which a scribe would encounter regularly (i.e. $\sigma v, \sigma o v, \sigma 01, \sigma \varepsilon$ ). Indeed, not only the spelling $\sigma 0 \mathrm{t}$ is sometimes found instead of the accusative, but also the form $\sigma v(4) .^{20}$

(4) P.Oxy. XXXI 2599(i), 26-29 (Oxyrhynchites, III-IV CE)

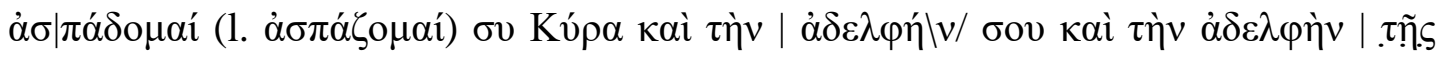

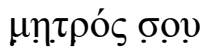

'I greet you, Kyra, and your sister and the sister of your mother.'

The papyrus contains two letters from Tauris: the first one to her father (11. 1-29) and the second to her brother (11. 30-37), written in a fast hand by the same scribe. Phonetic spellings are abundant in both letters; one of those is the spelling of $\langle v\rangle$ for $\langle 01\rangle$ of the dative case ending found in the greeting formulas of both letters, but see also $\pi \varepsilon \dot{\varepsilon} \mu \pi \omega \sigma v(1.24$ and 25-26),

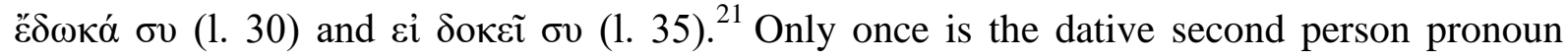
spelled as $\sigma o 1$, namely the first time it occurs at the beginning of the letter: $\pi \varepsilon \dot{\varepsilon} \mu \pi \omega$ бor $\tau \grave{\alpha}$ $\tau$ oi $\alpha \tilde{v} \tau \alpha$ (11. 10-11). The interchange of $\langle v\rangle$ and $\langle 01\rangle$ is very common in the papyri generally, pointing towards the merger of the sounds towards /y/ and later to /i/ (Gignac 1976: 197-199, 273). The dative pronoun is consistently spelled $\sigma v$ in this text and, therefore, it is likely that the dative was intended in the greeting formula as well. ${ }^{22}$ While the underdifferentiation of the vowels of the clitic pronouns might have created the circumstances for the confusion of the case endings, the phonetic conditions do not explain why it is precisely the dative case that is produced as an alternative for the accusative.

\subsubsection{Phraseological variation}

\footnotetext{
${ }^{20}$ Also in P.Oxy. LXII 4340, 29, 30 (TM 31664; Oxyrhynchos, ca. late III CE) and P.Oxy. LVI 3864,35 (TM 35475; Oxyrhynchos, V CE).

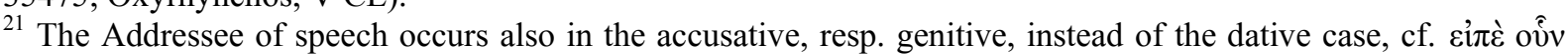

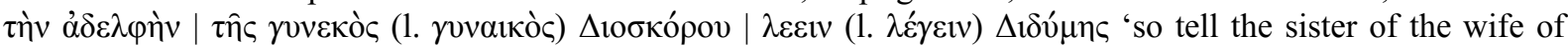
Dioskoros to say to Didyme' (11. 14-16). This confusion might be due to the weakness of the final $-v$ and $-\varsigma$ in pronunciation (Gignac 1976: 111-114; 124-126).

${ }^{22}$ There is no reason to think that the spelling ov was caused by the phonetic similarity of the dative and the accusative case endings in these two letters from Tauris. It seems rather due to the similarity of the nominative and dative form of the second person pronoun $(\sigma \nu-\sigma o t)$, since the dative of the first person singular is always spelled $\mu \mathrm{ot}$ in both letters $(11.9,30,32)$ and the second person singular only once as $\sigma 0 \mathrm{o}$ in the first letter (1. 11) and seven times as $\sigma v$ in the first (1l. 24, 26, 27) and second letter (1l. 31, 35, 36, 37) in various linguistic contexts.
} 
Another possible motivation for the use of the dative might have been confusion between the variant formulations of the salutation phrase. Confusion between phrases is found in the letter from Polybios to his father Herakleides (5).

\section{(5) SB XVIII 13593, 3-5 (Egypt, III-IV CE)}

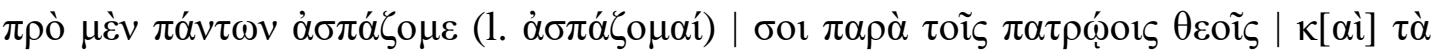

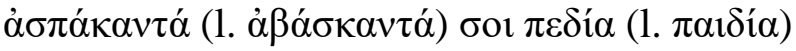

'Before all, I greet you in the presence of our ancestral gods and your children - may the evil eye not touch them.'

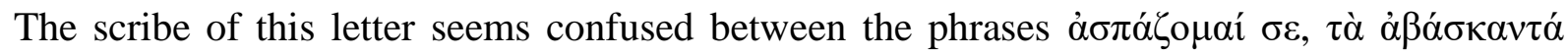

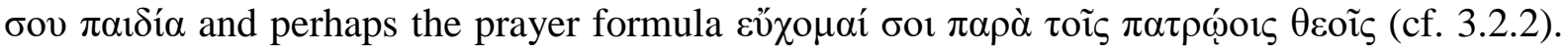

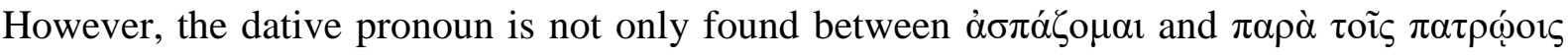
$\theta \varepsilon o i c$, but also in a different construction in the second part of the phrase which may be analogically formed to the greeting (see $\dot{\alpha} \sigma \pi \alpha ́ \kappa \alpha v \tau \alpha$ instead of $\alpha \dot{\alpha} \alpha \kappa \kappa \alpha \tau \tau)$ ). The noun phrase with the adjectival participle $\dot{\alpha} \beta \alpha ́ \sigma \kappa \alpha v \tau \alpha$ usually takes a genitive pronoun and not a dative one. ${ }^{23}$ Phraseological variation and analogical formation could explain the use of the dative pronoun in both phrases, if we assume the influence of a prayer formula (with oor as Beneficiary) on the salutation which then gets analogically extended to the second part.

The possibilities for phraseological variation in the salutation phrase are limited. First of all, we observe that different verbs are used to send regards: besides the popular $\dot{\alpha} \sigma \pi \alpha ́ \zeta o \mu \alpha 1$,

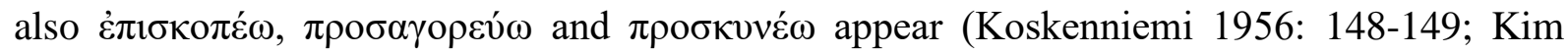
2011: 155-167). All of these verbs normally take an object in the accusative case. One might think that case variation could be related to the variation in verbs. As the majority of the interchanges occur with $\dot{\alpha} \sigma \pi \alpha \dot{\zeta} \sigma \mu \alpha$, let us first examine the remaining three examples of dative-accusative confusion with the verb $\pi \rho 0 \sigma \alpha \gamma o \rho \varepsilon v ́ \omega$. The letter in (6) consists for the most part of salutations to various people.

(6) P.Neph. 12, 4-6 and 13 (Omboi, 350 - 370 CE)

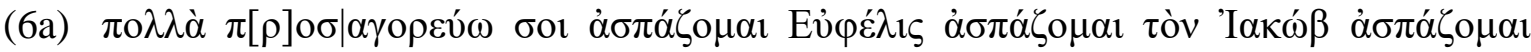

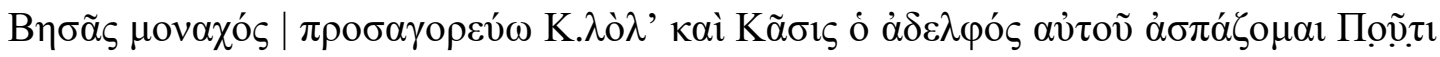

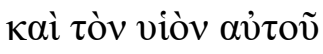

'I greet you repeatedly. I greet Euphelis. I greet Iakob. I greet the monk Besas. I greet Kelol and Kasis, his brother. I greet Poutis and his son.'

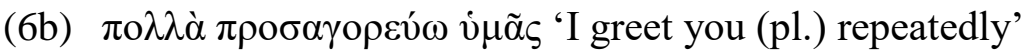

\footnotetext{
${ }^{23}$ Parássoglou (1986: 277) does not regularize the dative pronoun in the second instance, but notes that it is an "error" of the scribe (as in the first part of the sentence) or an "ethical dative". Another attestation of the dative instead of the genitive in this phrase can be found in P.Abinn. 30, 23-24 (TM 32672; Alexandria, mid IV CE)

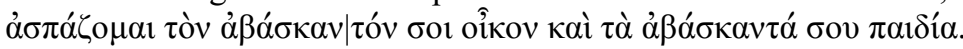


The letter in (6) is addressed to Nepheros, the head of a Meletian monastery in Phathor, and it belongs to a bilingual Greek-Coptic archive. ${ }^{24}$ In this list of greetings, almost all personal names remain uninflected and sometimes even full noun phrases are in the nominative case

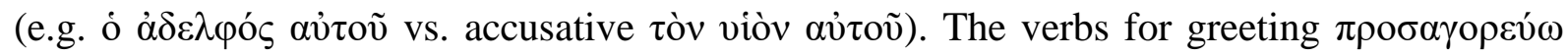
and $\dot{\alpha} \sigma \pi \alpha \dot{\zeta}$ o $\mu \alpha \mathrm{l}$ are used interchangeably in this letter and there does not seem to be a correlation with the case form they govern: $\pi \rho \circ \sigma \alpha \gamma o \rho \varepsilon v i \omega$ is used with a dative pronoun and with a nominative noun phrase (6a), but it is also constructed with an accusative plural pronoun (6b) later in the letter.

The dative case for the Addressee of greetings is also attested with nouns (7). The dative

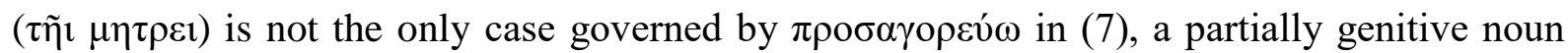

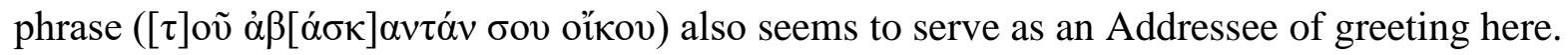

(7) P.Mich. VIII 519, 4-7 (Karanis, IV-V CE)

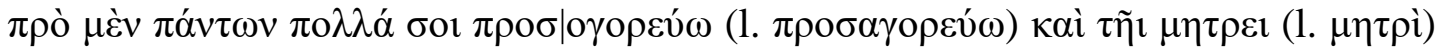

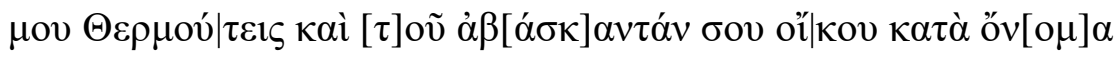

'Before all else I greet repeatedly you and my mother Thermoutis and your household - may the evil eye not touch them - each by name'

In P.Oxy. LVI 3864, 35 (Oxyrhynchos, V CE), dative for accusative substitution does not only occur in the salutations with $\pi \rho \circ \sigma \alpha \gamma o \rho \varepsilon v ́ \omega ;$ the closing formula also attests the same phenomenon. Thus, in all three examples, there are indications that the choice of verb is not related to the confusion of cases. The difference in frequency between the case interchanges

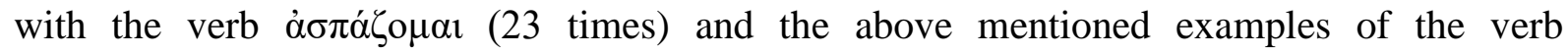
$\pi \rho о \sigma \alpha \gamma о \rho \varepsilon v ́ \omega ~(3$ times) reflects the normal distribution of the verbs in the periods in which dative-accusative interchange is attested. ${ }^{25}$

Another possible cause of phraseological confusion is the occasional use of the dative for the person on whose behalf the regards are sent. Such a dative is attested nine times in salutations from the sender to the addressee's social circle, including two letters sent by a certain Firmus to Exochos. These two ostraca were found in a deposit south of the fortified camp at Mons Claudianus and contain mostly greetings. ${ }^{26}$ Some of the personal names might be Latin (e.g. Firmus, Mescenius, Lupus) and some of the persons greeted could have been soldiers (cf. ed.pr.). Firmus systematically uses the dative $\mu$ or in combination with the greetings in his letters (8a).

\section{O.Claud. I 143, 5-9 and 10 (Mons Claudianus, 100-120 CE)}

\footnotetext{
${ }^{24}$ See also P.Lond. VI 1918, 3 (TM 16856; Phathor, ca. 330-340 CE) addressed to Paieous, a predecessor of Nepheros as head of this Meletian community, which shows the same lack of declension and the same kind of case interchanges.

${ }^{25}$ The verb $\alpha \sigma \pi \alpha ́ \zeta o \mu \alpha t$ is frequently used throughout the Roman period, whereas the verb $\pi \rho \circ \sigma \alpha \gamma o \rho \varepsilon v i \omega$ starts to

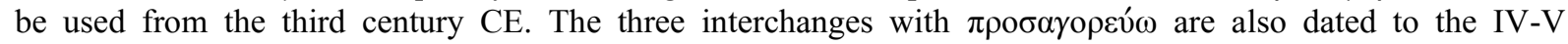

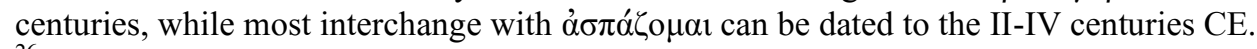

${ }^{26}$ Other attestations are found in another letter by Firmus: O.Claud. I 144, 4, 5 and 8 (TM 24156; Mons Claudianus, 100-120 CE), as well as in P.Euphr. 17, 26 (TM 44675; Syria, mid III CE); P.Oxy. XIV 1773, 36 (TM 31815; Antinoopolis, III CE); P.Oslo III 161, 7 and 9 (TM 31642; Egypt, late III-IV CE); P.Kellis I 71, 27, 39, 41 (TM 33325; Kellis, mid IV CE); P.Kellis I 72, 38 (TM 33326; Kellis, mid IV CE); P.Herm. 43, 6 (TM 33478; Egypt, IV CE); P.Oxy. LVI 3862, 18 (TM 33603; Oxyrhynchos, IV-V CE).
} 


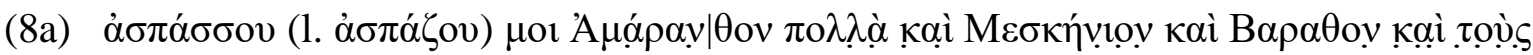

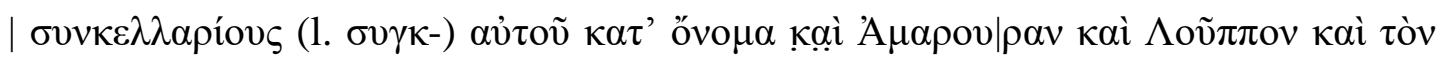

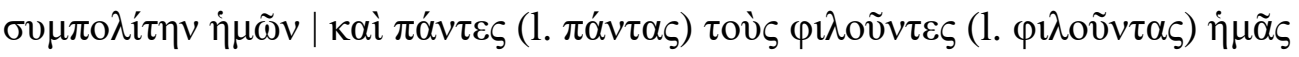

'Greet for me Amaranthos many times and Mescenius and Barathos and his synkellarioi by name and Amarouras and Lupus and our fellow-citizen and everyone who loves us.'

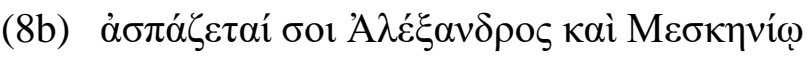

'Alexandros greets you and Mescenius'

Perhaps, the scribe associated the verb $\dot{\alpha} \sigma \pi \alpha \dot{\alpha}$ o $\mu \alpha$ with the dative case, and transferred the use of a dative from the salutations to third parties ( $\dot{\alpha} \sigma \pi \alpha$ cov $\mu$ or 'greet for me NN') to the salutations from his own social circle to the addressee ( $\alpha \sigma \pi \alpha$ $\zeta \varepsilon \tau \alpha i$ $\sigma o 1$ 'NN greets you'). This would then explain the use of the dative $\sigma o r$ instead of the accusative $\sigma \varepsilon$ in the greeting formula in the next line (8b).

Even though the use of a dative pronoun to express emotional closeness to the Beneficiary of the greetings might have caused some confusion for Firmus, it does not seem to have had an impact more generally: most importantly, the expression of the Beneficiary $\mu$ or was not widespread. Furthermore, other letters with the dative $\mu \mathrm{o}$ in the salutations from the sender to the addressee's social circle do have the accusative $\sigma \varepsilon$ when the sender's relatives and friends are sending their regards to the addressee. ${ }^{27}$

\subsubsection{Semantics and syntax}

Phonetic similarity could have played a role in the confusion of case endings of the second person singular pronoun, but it does not directly explain the choice for the dative case ( $\sigma \circ 1)$ rather than the spelling of any other vowel (3.1.1). Furthermore, phonetic similarity cannot easily explain why dative-accusative interchange is occasionally attested in plural pronouns and nominal forms as well, cf. (7), (8b) and (9).

(9) P.Oxy. LVI 3859, 46-50 (Oxyrhynchos, IV CE)

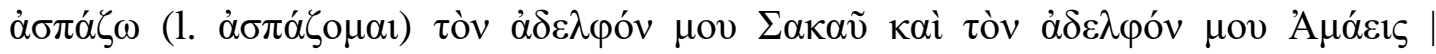

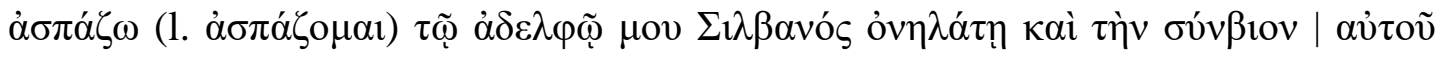

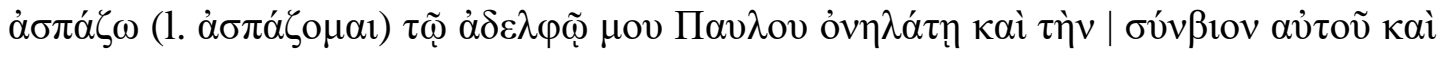

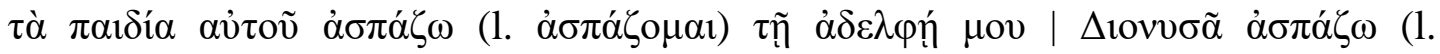

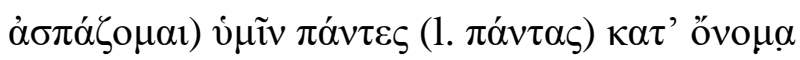

\footnotetext{
${ }^{27}$ For instance, in P.Kellis I 72 (TM 33326; Kellis, mid IV CE), another attestation of $\mu$ or (cf. supra), the salutations from the sender's social circle to the addressee are correctly constructed with the accusative:

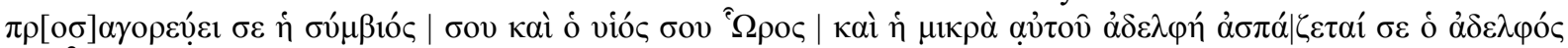

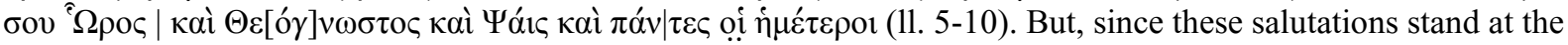
beginning of the letter and those with the dative as beneficiary are placed at the end, this could have prevented influence from the dative.
} 
'I greet my brother Sakaus and my brother Amaeis. I greet my brother Silvanos, donkey-driver, and his wife. I greet my brother Paulos, donkey-driver, and his wife and his children. I greet my sister Dionysa. I greet you, all by name.'

The letter from Horigenes to Sarapammon is written in a skilled hand and it contains a long list of salutations (11. 25-50), all of which with the unusual active first person singular form of the verb for greeting: $\dot{\alpha} \sigma \pi \alpha ́ \zeta \omega$ instead of $\dot{\alpha} \sigma \pi \alpha ́ \zeta$ o $\mu \alpha$. All noun phrases following $\alpha \sigma \pi \alpha ́ \zeta \omega$ are

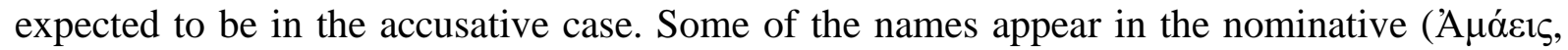

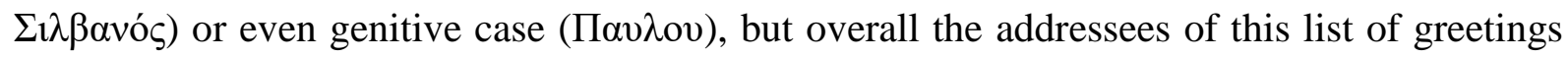

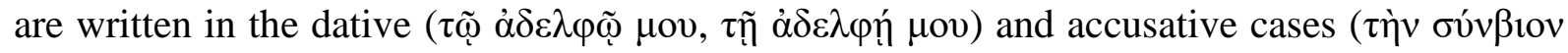

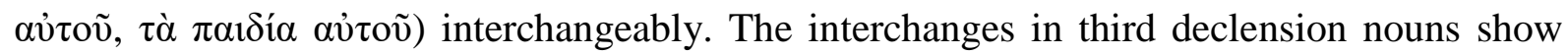

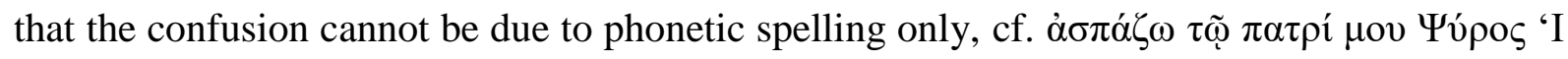

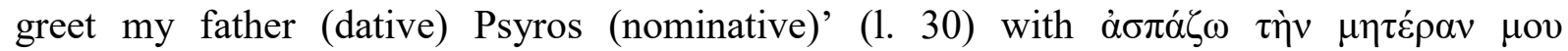

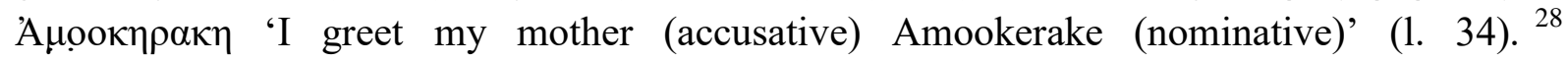
Interchanges of dative and accusative pronouns seem often attested in letters that also contain phonetic spellings, cf. (3)-(4), (7), and/or other case interchanges, cf. (2)-(3), (6)-(7) and (9). ${ }^{29}$ The problems with case inflection may be caused by Egyptian scribes writing Greek, e.g. (6) and (7), although this is not likely to be the only reason for case interchange, cf. (5) and (8). ${ }^{30}$ Even if some of the scribes do indeed have an Egyptian background, why would they be tempted to write the dative case with the verbs for greeting?

A possible similarity with the dative function of Beneficiary was noted above (3.1.2), but this overlap cannot be easily be demonstrated for salutation formulas in general. Another interesting comparison to the dative-accusative interchanges with greeting verbs can be found in the following letter (10).

(10) P.Mich. VIII 482, 8-14 (Karanis, 23.08.133 CE)

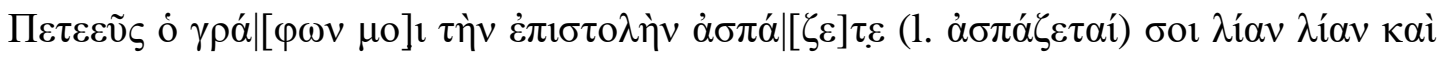

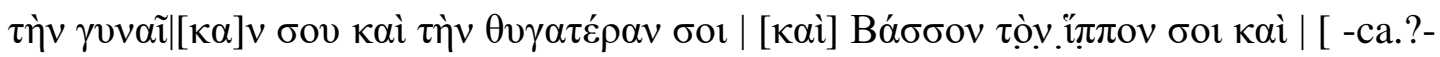

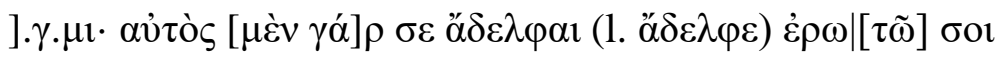

'Peteeus, who is writing the letter for me, greets you repeatedly and your wife and your daughter and Bassos your horse and [?]. For I myself ask you, brother'

The language of this letter is peculiar and the dative seems to serve as the default case in this section. It occurs not only after the verb for greeting ( $\dot{\alpha} \sigma \pi \alpha \dot{\alpha} \zeta \varepsilon \tau \alpha \iota ~ \sigma o \imath)$, but it is also used for

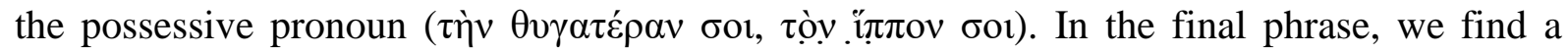
different verb that seems to deviate between a dative and an accusative pronoun: $\dot{\varepsilon} \rho \omega \tau \alpha \dot{\omega} \omega$ 'to

\footnotetext{
${ }^{28}$ The nominative may be explained by the special status of personal names (Adams 2013: 206-212).

${ }^{29}$ Although not exclusively; in some of the earlier texts, e.g. P.Harr. I 103, 12 (TM 28709; Oxyrhynchites, II CE); P.Giss.Univ. III 26, 14 (TM 31818; Egypt, III CE) and SB V 8002, 27 (TM 30792; Egypt, III CE), few orthographic and morphosyntactic deviations are found, apart from the dative for accusative pronoun in the greeting formula.

${ }^{30}$ Dative for accusative case interchange in greeting formulas is also found outside of Egypt, e.g. P.Dura 46 (TM 30498; Syria, early III CE) contains a letter from Barsabbathas, a soldier at Antioch, to Heliodoros, a centurion at Dura.
} 


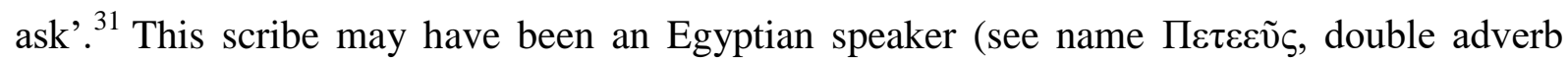
$\lambda i ́ \alpha v \lambda i ́ \alpha v)$, but this does not mean that all deviations from standard written Greek have to be caused by bilingual interference from his native language. The confusion between the dative and the accusative with verbs for asking occurs more often. If the reading and interpretation of the verb phrase in (11) is correct, this letter provides another example. ${ }^{32}$

(11) SB XXVI 16608, 6-9 (Oxyrhynchos, early I CE)

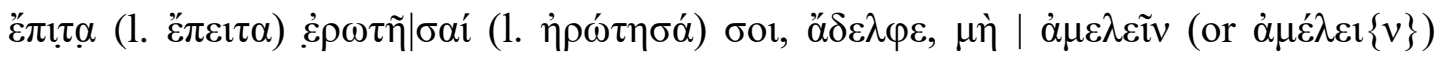

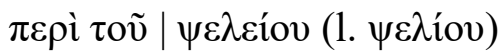

'Next I asked you, brother, do not be neglectful about the bracelet.'

Bagnall (1999: 113-114) explains the assumed case interchange in (11) as follows in the commentary to the edition (n. to 1. 7):

"Alain Martin points out that there are other instances of $\dot{\varepsilon} \rho \omega \tau \alpha \dot{\omega} \omega$ with the dative (P.Mich.8.482, 14, 17, 18; P.Rain.Cent.76.1), and that the analogy of $\delta \varepsilon$ c $_{\mu \alpha}$, another verb of asking is perhaps instructive: Willy Clarysse has noted (CE 68, 1993, 198) that its occurrence with the dative is a sign that the writer is a native speaker of Egyptian, for whom this construction would be normal."

The first author of this article has argued elsewhere (Stolk forthcoming) that the construction of $\delta \varepsilon$ ć $\mu \alpha$ with a dative pronoun cannot be explained by direct transfer from Egyptian, but rather through creative interpretation of the rules of the Greek language by second language learners. Verbs for greeting in Egyptian seem to take various types of complement phrases,

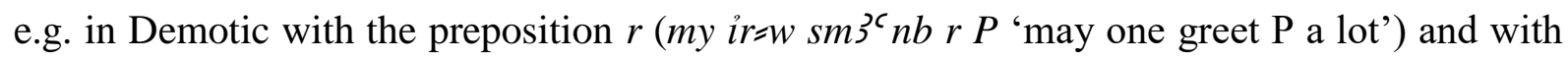
the preposition $n$ (my $i r=w n 3 s m 3^{`}$ ' $w n$ P 'may one greet P') during the IV-III centuries BCE

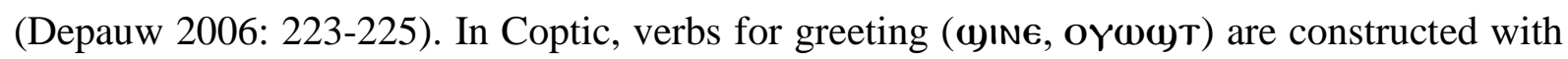
the prepositions $\epsilon-$ 'to' and $\mathrm{N}$ - 'at, for' (Crum 1939: 504, 569-570; Biedenkopf-Ziehner 1983: 79-104). The preposition $\mathrm{N}$ - only distinguishes between direct object (MMO=) and indirect object $(N \alpha=)$ with personal pronouns. Egyptian scribes could, therefore, have identified the pronominal indirect object preposition as corresponding to a dative pronoun in Greek.

\footnotetext{
${ }^{31}$ Dickey (2010) argues that the common pair $\dot{\varepsilon} \rho \omega \tau \hat{\omega}$ and $\pi \alpha \rho \alpha \kappa \alpha \lambda \hat{\omega}$ is based on Latin verbs rogo and oro, resp. 'ask' and 'request', because they are not only constructed with infinitive (as already common with indirect command in Greek for $\pi \alpha \rho \alpha \alpha \lambda \lambda \hat{\omega}$, but new from the I CE for $\dot{\varepsilon} \rho \omega \tau \hat{\omega}$ ), but also with imperative (from I BCE) and subjunctive (from I CE) which is also possible with the Latin equivalents.

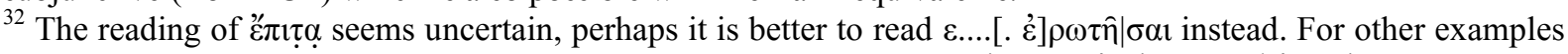

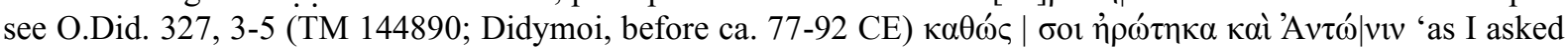

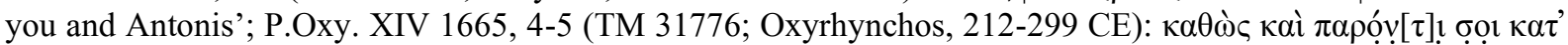

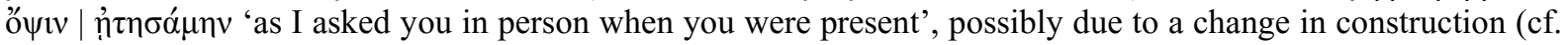

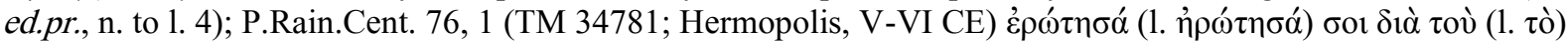

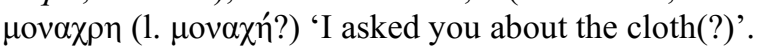


Egyptian interference can only be part of the explanation of this phenomenon, as the alternation between dative and accusative with verbs for asking and ordering, such as $\dot{\varepsilon} \rho \omega \tau \alpha \dot{\alpha} \omega$,

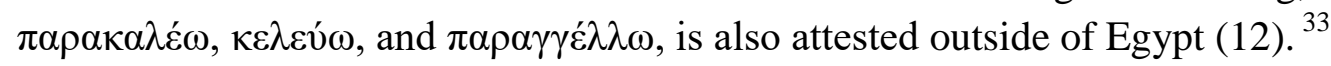

(12) P.Ness. III 53, 3 (TM 21485; Nessana, 608? CE)

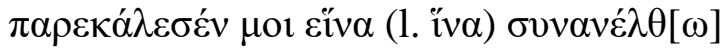

'he requested me to travel up with him'

The letter in (12) is written by the abbot and priest Patrikios son of Sergios from Nessana in Palestine (P.Ness. III 44-47). The papyrus is fragmentarily preserved, but it seems that a dative pronoun is used in the disclosure formula (cf. 3.2.3) and with the verb $\pi \alpha \rho \alpha \kappa \alpha \lambda \varepsilon \dot{\varepsilon} \omega$, while an accusative pronoun might be attested with the same verb in 11.6 and 8. The dative case is also attested with verbs such as $\alpha i \tau \varepsilon \dot{\varepsilon} \omega$ and $\pi \rho 0 \sigma \kappa v v \varepsilon \dot{\varepsilon} \omega$ in the Chronicle of Malalas (Thurn 2000: 510). The same alternation between dative and accusative is observed with some verbs used by Hellenistic authors and in the New Testament (Moulton-Turner 1978: 236; Riaño 2006: 502-508). ${ }^{34}$

Greek verbs for greeting as well as verbs for asking and requesting are expected to take an accusative Addressee, whereas many other communication verbs take a dative complement, such as $\lambda \dot{\varepsilon} \gamma \omega$ 'to say' (cf. examples in Sevdali and Anagnostopoulou 2013). Therefore, the interchange of dative for accusative involves an analogical extension of the argument structure of the more productive category of (ditransitive) verbs taking a dative complement towards the category of (di)transitive verbs with an accusative complement (Riaño 2006: 503). The interchange does not necessarily reflect a stage of case alternation in the contemporary spoken language, but it does explain the cognitive processing mechanism responsible for this type of scribal variation (cf. Bybee 2010: 72-73). Because the scribes have learned that the Addressee of speech is commonly denoted by a dative case in Greek, they may overextend this use of the dative case to other Greek communication verbs as well.

\subsection{Health wish $^{35}$}

\footnotetext{
${ }^{33}$ A dative instead of an accusative pronoun may also be attested for other verbs usually taking an accusative in

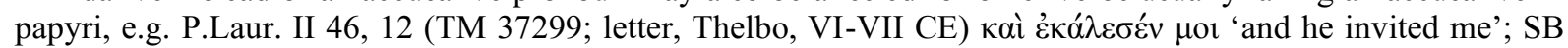

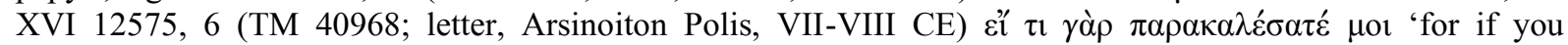
requested something of me'.

${ }^{34}$ Riaño shows that some verbs for ordering and asking, such as $\kappa \varepsilon \lambda \varepsilon v ́ \omega, \pi \alpha \rho \alpha \gamma \gamma \varepsilon \dot{\varepsilon} \lambda \lambda \omega$ and $\pi \alpha \rho \alpha \kappa \alpha \lambda \varepsilon^{\prime} \omega$, alternate between dative and accusative second complements between the second century BCE and the second century CE (i.e. in Polybius, Vitae Aesopi G, Gospel of Luke and Acts of the Apostles). He concludes that based on verbs for saying (dative second complement) and asking (accusative second complement) it cannot be argued that the dative case has declined between the fifth century BCE and the second century CE.

${ }^{35}$ There are 26 texts with a dative instead of the accusative second person singular pronoun in health wishes (cf. table 3). The following 10 are found at the beginning of a letter: O.Did. 350, 4 (TM 144911; Didymoi, before ca. 77-92 CE); SB IV 7354, 4 (TM 27385; Egypt, early II CE); BGU III 815, 2 (TM 9366; Arsinoites, 140-143 CE); O.Claud. II 224, 4 (TM 29647; Mons Claudianus, mid II CE); P.Mich. III 206, 3 (TM 28795; Karanis, ca. late II CE); P.Leid.Inst. 42 (1l. 1 - 19), 3 (TM 27729; Philadelpheia, II CE); P.Leid.Inst. 42 (11. 20 - 28), 22 (TM 43134; Philadelpheia, II CE); BGU II 384, 3 (TM 28132, Arsinoites, II-III CE); P.Abinn. 31, 4 (TM 10028; Arsinoites, ca. 346 CE); P.Oxy. X 1299, 3 (TM 33637; Oxyrhynchos, IV CE). And in 16 more texts in the closing formula: P.Mich. VIII 482, 7, 18 (TM 17241; Karanis, 23.08.133 CE); P.Mich. III 206, 24 (TM 28795; Karanis, ca. late II CE); P.Gron. 19A, 16 (TM 29212; Egypt, II CE); BGU II 615 (i), 17 (TM 28191; Arsinoites, II CE); BGU II 615
} 


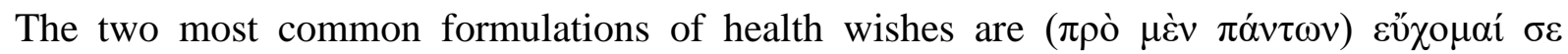

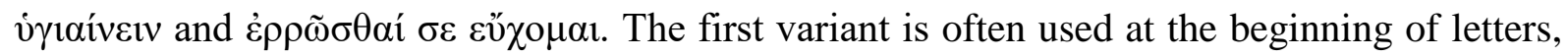
hence called 'initial health wish', whereas the second formulation is commonly used as a closing formula. ${ }^{36}$ Case interchange seems more common in the initial health wish than in the closing formula (cf. table 3, section 2.3). In this section, we discuss the possible motivations for the interchange of dative for accusative in both health wishes, also taking into account the differences in the distribution of case interchanges between them. Factors under consideration are again the phonetic similarity of the vowels of the case endings of the personal pronoun and the scribal context of the phrase (3.2.1), the possibilities for confusion due to phraseological variation (3.2.2) and the semantic and syntactic similarity of the dative and the accusative case in the construction of the health phrase (3.2.3). ${ }^{37}$

\subsubsection{Phonetic similarity and scribal context}

For the greeting formulas, it has been observed that the conditions for the confusion between the dative and the accusative could have been created by the lack of distinction in the pronunciation between the $<_{01}>$ and $<_{\varepsilon}>$ in clitic pronouns (3.1.1). For the health wishes, phonetic similarity might have been even more important, since the pronoun is always

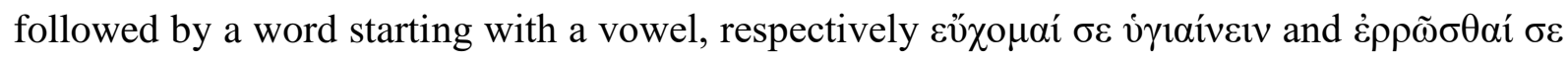

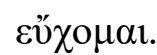

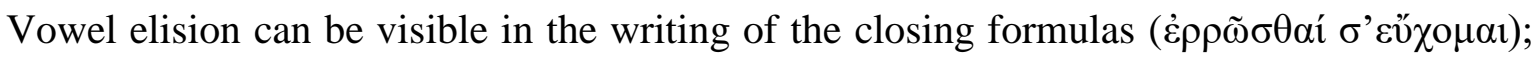
the entire corpus of over 4,000 private letters has about 25 occurrences. ${ }^{38}$ The lack of phonetic

(ii), 33 (TM 28191; Arsinoites, II CE); P.Giss. I 97, 16 (TM 27875; Alexiandria, II CE); P.Oxy. VIII 1158,25 (TM 31724; Alexandria, III CE); P.Oxy. VII 1068, 28 (TM 31315; Oxyrhynchos, III CE); P.Oxy. IX 1220,26 (TM 31651; Oxyrhynchos, III CE); P.Oxy. XXXI 2602, 16 (TM 32693; Oxyrhynchites, early IV CE); SB XII 10841, 21 (TM 32558; Oxyrhynchos, IV CE); P.Oxy. XLVIII 3418, 12 (TM 33724; Oxyrhynchos, 330-385 CE); P.Oxy. XLVIII 3400, 28 (TM 22492; Oxyrhynchos, ca. 359-365 CE); P.Oxy. LVI 3864, 36 (TM 35475; Oxyrhynchos, V CE); SB VI 9400, 23 (TM 36839; Arsinoites, mid VI CE); PSI VII 835, 25 (TM 36189; Oxyrhynchos, second half VI CE). Another example may be found in an unpublished papyrus letter from the collection of the University of Oslo Library, inv. 485, 1. 25 (Egypt, II-III CE).

${ }^{36}$ Sometimes, the closing formula is found in a different position, e.g. P.Oxy. IX 1220, 26 (TM 31651; Oxyrhynchos, III CE) where the closing formula ended up in the middle of the text; P.Mich. VIII 482, 7, 18 (TM 17241; Karanis, 23.08.133 CE) has a double closing formula, following a double post-scriptum (cf. Kim 2011: 107-110). In P.Mich. III 206, 3 (TM 28795; Karanis, ca. late II CE) the formulation of the closing formula is found at the beginning (1.3) and end of the letter (1. 24), perhaps due to influence from Latin where the same words are used in the beginning and end of the letter, only in a different order (Halla-aho 2008: 49-56).

${ }^{37}$ A number of instances of the health wish have been left out of the discussion due to poor preservation of the pronoun or the phrase. In PSI VIII 943, 3-5 (TM 27224; Egypt, II CE), the reading of oot is too uncertain (Bell

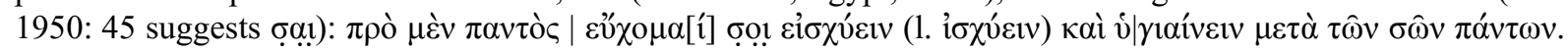
The health wish in P.Köln X 418, 2-3 (TM 47279; Egypt, III-IV CE) is also too fragmentary to be included: [ca.?

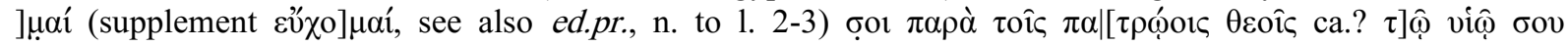

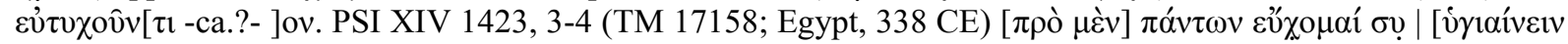

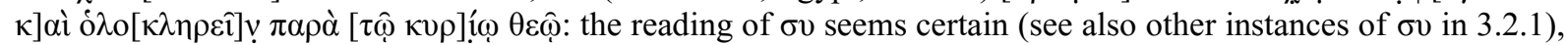

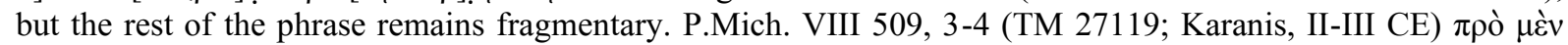

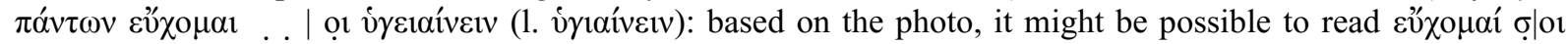

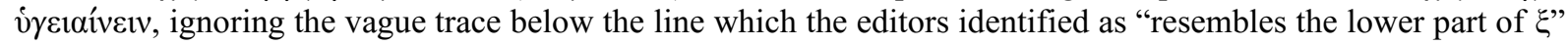
(ed.pr., n. to 1. 3-4), although the line break in the middle of the word is surprising and a reading of a small $\sigma[\varepsilon]$ at the end of line 3 cannot be ruled out.

${ }^{38}$ The ed.pr. of CPR VIII 52 as well as the new edition in SB XX 14226 read $\sigma \varepsilon \sigma \chi 0 \mu \alpha$ (1. 27), but it might be

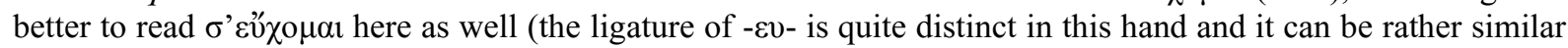

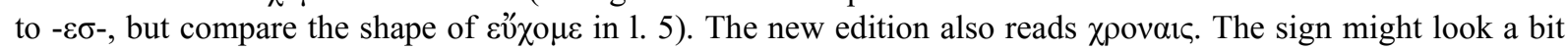


distinction of the pronouns in this phrase is not only visible in the elision of the vowel; the reference to the addressee could even be omitted altogether. This is, for instance, found on the ostracon in (13), written by Dioskoros, a vegetable farmer in the surroundings of the Roman quarry at Mons Claudianus. The dative-accusative case interchange in the health wish (13a) co-occurs with the lack of case inflection in the name of the addressee in this letter (the same happens in O.Claud. II 279, 1 and 15). ${ }^{39}$ Leiwo (2003: 82-89) has argued that both these ostraca (O.Claud. II 224 and 279) were written by Egyptian scribes and the lack of case inflection might be typical for Egyptians with Greek as a second language. Adams (2013: 206-213) adds that there might have been some idiolects (e.g. in Mons Claudianus ostraca) where the nominative of personal names is treated as an "invariant form". However, this does not account for the interchange between dative and accusative in the initial health wish (13a).

(13) O.Claud. II 224, 3-4 and 13 (Mons Claudianus, mid II CE)

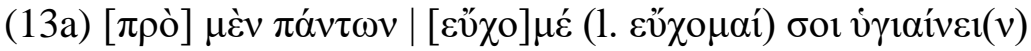

'Before all, I wish you to be healthy'

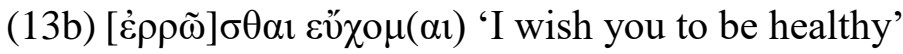

In this case, the phonetically weak position leading to the omission of $\sigma \varepsilon$ (13b) might also explain the uncertainty as to how to spell the pronoun in the initial health wish (13a). In the corpus of private letters, the omission of the pronoun is attested ten times for the initial health wish $^{40}$ and about fifty times for the closing formula. ${ }^{41}$ The formulas were widely known so that an omission would not cause confusion for the reader of a letter, who knew these standard phrases by heart and did not have to see them written. In this sense, the exact formulation and orthography of the formula was nothing more than a convention. This can be observed from the omission of elements, but also from the way in which the closing phrase is written in many letters. Due to the writing style it is often uncertain whether the closing formula was actually written by the same scribe as the body of the letter or by a different person, perhaps the author. This has been noted, for example, for a letter from the Neilos archive (14), authored by his sister Tasoucharion (see also example 2). The editors considered the second part of the letter to be written in a second hand, but Bagnall and Cribiore (2006: 181) note that "it is probably one, the hand of a person (perhaps Tasoucharion herself) for whom writing was not a daily concern". This lack of experience could be partly responsible the variation between the expected accusative pronoun in the initial health wish (14a) and the dative pronoun in the closing formula (14b).

like alpha on the photo in the print edition (Paul 1992: 77), but this interchange is very rare and based on the

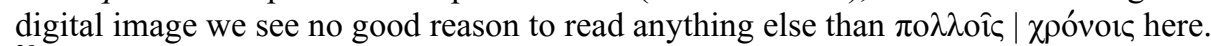

${ }^{39}$ There is no reason to assume that this is related to the Latin context of the army (Leiwo 2003; 2005; Adams 2013: 210). Several letters of Dioskoros are preserved and generally the name of the addressee remains

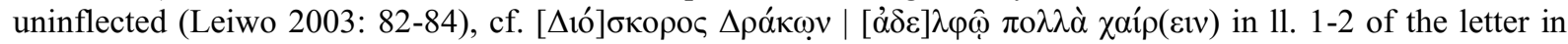
(12). This may be due to the special status of the nominative case of personal names (Adams 2013: 206-212).

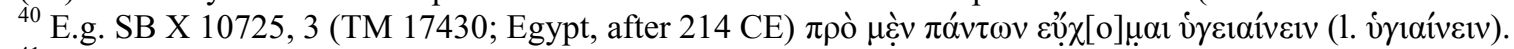

${ }^{41}$ The closing formula is also shortened in other ways: in eight letters dated between the I-II and the V centuries $\mathrm{CE}$, the main verb or the infinitive are omitted, e.g. resp. P.Abinn. 6, 27 (TM 10051; Arsinoites, ca. 346 CE)

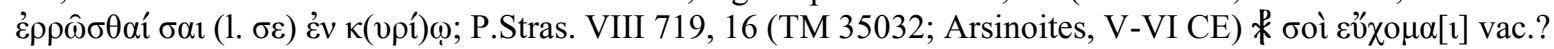


(14) P.Giss. I 97, 3-6 and 16 (Alexiandria, II CE)

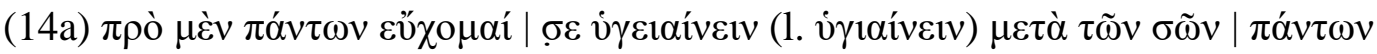

'Before all, I wish you to be healthy with all your people'

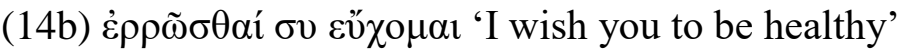

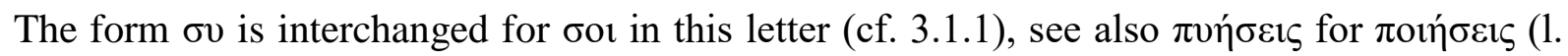
8) and $\tau \alpha$ $\sigma v$ है $\mid \pi \varepsilon \mu \psi \alpha$ (1. 6-7). In the course of the letter the handwriting and language become more irregular. The end of the closing formula does not seem to have received a lot of attention: the last part of $\varepsilon v " \chi o \mu \alpha$ is sketchy and the ink is fading. This lack of attention is often encountered in closing formulas. ${ }^{42}$

Could the lack of importance of the exact formulation of the closing formula really explain the interchange of cases? Or is it not rather the other way around: because the closing formula was so conventional, every scribe should know how to write it? The highly formulaic character of the phrase could be the reason why case interchange does not occur more often in closing formulas (cf. table 3, section 2.3). Bagnall and Cribiore (2006: 274) note about (15): "the letter is correctly written only in the formulaic parts; the rest contains every kind of error". This is a common point of view on the difference between the language of fixed phrases and the language of the body of a private letter. However, this does not mean that fixed phrases do not show any variation, as can be observed in many of the letters shown in this article. For example, the salutation phrases in (15) are indeed largely standardized in terms of orthography in contrast to the body of the letter, but all of them contain oot for the Addressee of the greetings (4 times, in 11. 4-5 and 11. 11-13) and also the initial health wish is constructed with ool (15a). The closing formula does contain the expected accusative pronoun in the plural (15b).

(15) P.Oxy. X 1299, 3-4 (Oxyrhynchos, IV CE)

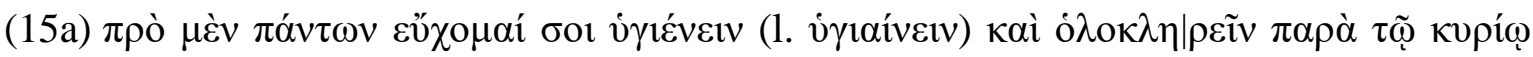
$\theta \varepsilon \tilde{\varphi}$

'Before all, I pray for you to be healthy and sound, in the presence of the lord god'

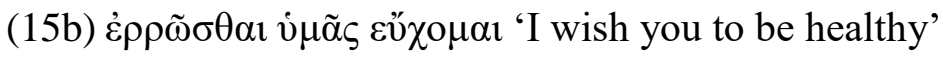

Perhaps letters could have influenced each other: people imitated the fixed phrases that other people used in their communication. In this way, variants may have spread. For instance, (16) contains two letters on one sheet. The first letter, running from lines 1-19, was sent by Heras to her sister Taphes and contains an initial health wish with $\sigma 01$ (16a).

\footnotetext{
${ }^{42}$ E.g. a similar lack of eye for detail is observed in P.Oxy. XLVIII 3418, 12 (TM 33724; Oxyrhynchos, 330-385

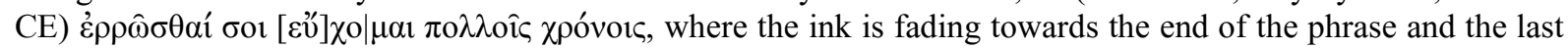

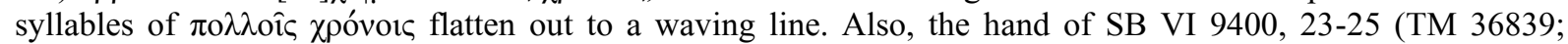

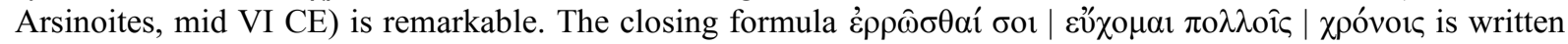
in an experienced, but rather shaky hand. There could have been several reasons for the difficulty with which the letters are formed other than incompetence, e.g. the age of the scribe (cf. Cromwell 2010).
} 
(16) P.Leid.Inst. 42, 3-4 and 22-23 (Philadelpheia, II CE)

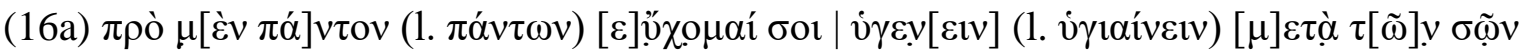

'Before all, I pray that you and your family are in good health'

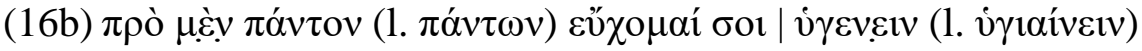

'Before all, I pray that you are healthy'

The second letter (from lines 20-28) is the response from Taphes to her sister. It was written in the same hand, probably by the person who carried the letter, and it contains an almost identical health wish (16b). The non-standard spellings of $\pi \alpha \dot{v} \tau \tau o v$ instead of $\pi \alpha ́ v \tau \omega v$ and of

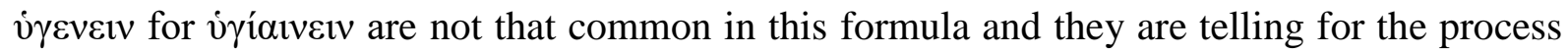
by which the letter was drawn up. Perhaps, the scribe had learnt this phrase with its (orthographical and other) deviations by heart and he would write the initial health wish in this way every time he wrote a letter. However, it seems more likely that the scribe chose the easy option of simply copying what he had written in the first letter. ${ }^{43}$

Variation in the formulation of epistolary phrases is not as predictable as one might expect from the conservative nature of fixed formulas. ${ }^{44}$ The variation is found at several levels of the language: orthography, morphology, syntax and phraseology. The orthography of phrases that sounded similar in pronunciation possibly shows us a mixture of the scribe's memory of previous encounters with the phrase and his intuition regarding the structure of the language, possibly influenced by his own linguistic background. This even, or perhaps especially, applies to the construction of formulaic phrases which - due to their conservative nature might have been more difficult for the scribe to understand and remember in their correct form, visually or aurally.

\subsubsection{Phraseological variation}

\footnotetext{
${ }^{43}$ Also in BGU II 615 (TM 28191; Arsinoites, II CE) two letters were written in succession on the same papyrus sheet, and both have a closing formula with $\sigma 01$ instead of $\sigma \varepsilon$. In this case, the palaeography is less clear: the editor notes that both letters are written in the same hand, but that the closing formulas are in a faster hand; yet, it is not entirely clear if these phrases are indeed written by the senders of the two letters (Bagnall and Cribiore 2006: 395-396). If the closing formulas were written by the senders, Celer, the sender of the second letter, might have modelled his phrase on that of Ammonus' letter. However, the closing formulas are not the only similarity between the two letters. If one scribe was responsible for the whole, then the closing formula could be viewed

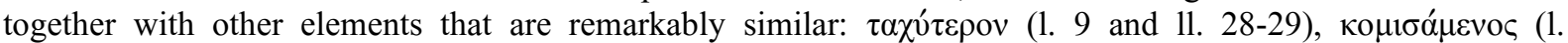

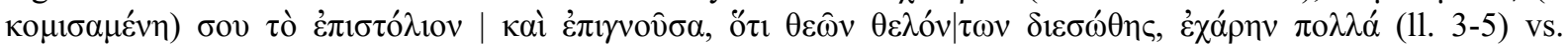

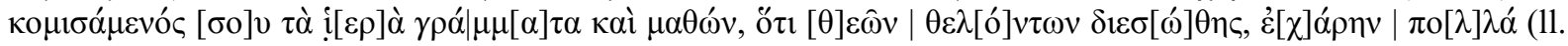

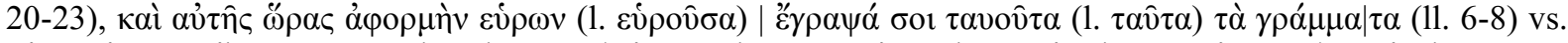

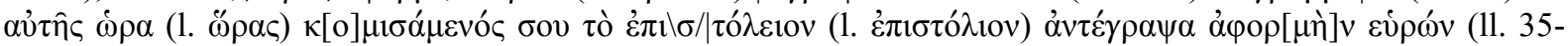
36).

${ }^{44}$ Letters from the same archive might also share the interchange of dative for accusative, e.g. two letters from the Saturnila archive: P.Mich. III 206, 3, 21, 24 (TM 28795; Egypt, ca. late II CE) and P.Mich. III 209, 18 (TM 28798; Karanis, ca. late II CE). However, these letters are written in different hands and were sent by different persons (resp. Longinus Celer and Saturnilus). The letter from Longinus Celer has the dative pronoun in the initial and final health wishes as well as in a salutation formula, while the letter from Saturnilus only uses the dative pronoun in the salutation and seems to have $\sigma \alpha l(1 . \sigma \varepsilon)$ in the health wishes. There does not need to be a shared explanation for these occurrences.
} 
Whereas the formulation of the closing formula is largely fixed and variation is mainly found in the orthography and omission of elements (3.2.1), the initial health wish can be formulated in various ways. Besides the commonly attested infinitive clause, i.e. ( $\pi \rho o ̀ ~ \mu \grave{\varepsilon ̀ v} \pi \alpha ́ v \tau \omega v$ )

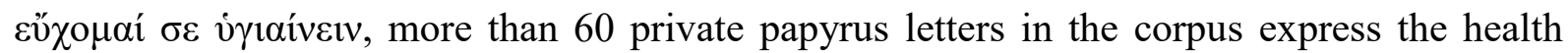
wish with a substantive. ${ }^{45}$ Several variants are attested (17)-(20).

(17) SB XIV 12080, 3-5 (Egypt, IV CE)

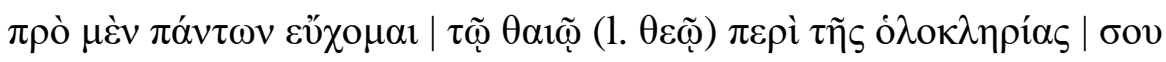

'Before all, I pray to the god for your well-being'

(18) P.Oxy. LVI 3865, 5-8 (Oxyrhynchos, late V CE)

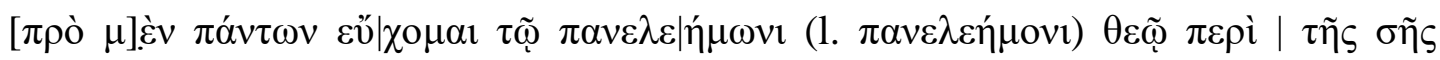

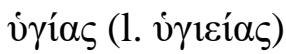

'Before all, I pray to the all-merciful god for your health'

(19) P.Lond. VI 1917, 2-3 (Phathor, ca. 330 - 340 CE)

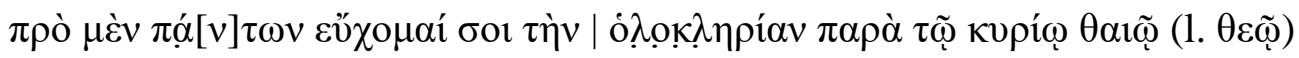

'Before all, I pray for well-being for you in the presence of the lord god'

(20) PSI IX 1042, 3-4 (Egypt, III CE)

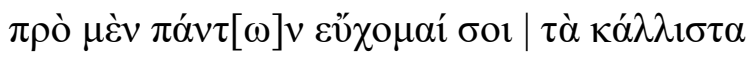

'Before all, I wish you the best'

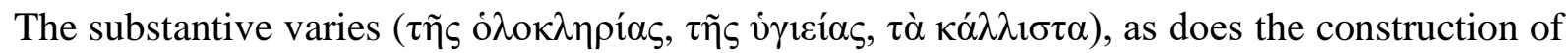
the participants: the Addressee, the Beneficiary and the contents of the wish or prayer. The verb cứoual could take a dative Addressee 'to pray/wish to', see (17)-(18), but it might also construct with a dative as a Beneficiary 'to pray/wish for', see (19)-(20). In the first construction, the content of the prayer is denoted by a prepositional phrase ( $\pi \varepsilon \rho i$, cf. 17-18) and the Beneficiary is connected to the content as a genitive possessive pronoun $(\sigma o v, 17)$ or an adjectival possessive pronoun $(\sigma \tilde{\eta} \varsigma, 18)$. In the second phrase, the content of the wish forms the direct object of the verb (19-20) and it is possible to add the addressee of the prayer by an adverbial clause, such as $\pi \alpha \rho \alpha$ + dative. ${ }^{46}$ In all, the dative pronoun is used without any problem in the variant formulations of the initial health wish (19-20) and phraseological

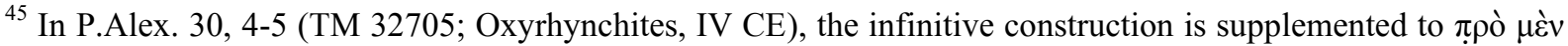

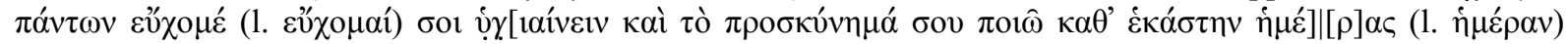

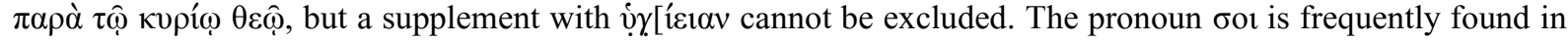
the construction with a substantive, also without the article, e.g. P.Mich. VIII 497, 8-9 (TM 27107; Arsinoites,

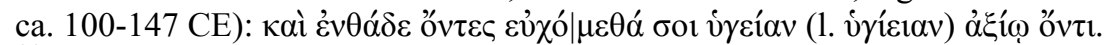

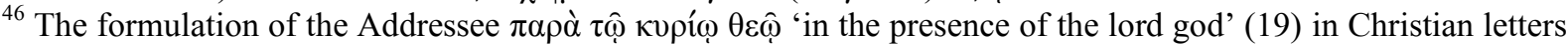
might continue an older Egyptian phrase, cf. (5), since the Addressee of the health wish is usually denoted by the dative case, cf. (17)-(18), or the preposition $\dot{\varepsilon} v$ in the Septuagint and NT (Kim 2011: 153-154).
} 
confusion between the phrases could have caused some of the attestations of dative pronouns in the more frequent form of the health wish with an accusative and infinitive construction. ${ }^{47}$

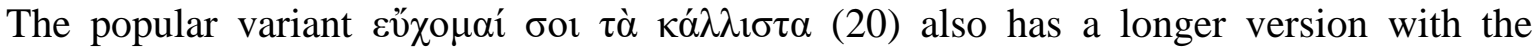
passive infinitive of the lexical possessive predicate vं $\pi$ ó $\chi \omega$ 'to be' (21).

(21) P.Oxy. XXXVI 2783, 2-3 (Oxyrhynchos, III CE)

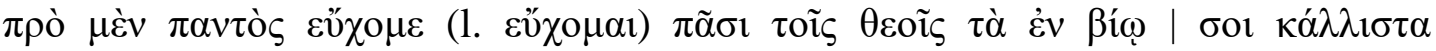
نं $\pi \rho \rho \theta \tilde{\eta} v \alpha \imath$

'Before everything, I pray to all gods that the best things in life are yours.'

The prayer is addressed to the gods (dative) and the contents of the prayer are constructed as an accusative and infinitive clause, but - instead of the Beneficiary/Experiencer $\sigma \varepsilon$ as the

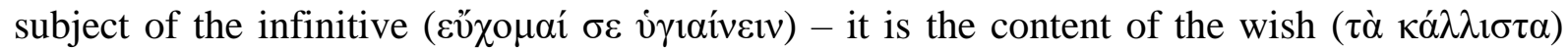
that is formulated as the subject. The Beneficiary is constructed as a predicative possessor of the 'good things'. This means that the Beneficiary/Possessor should be denoted by a dative in this phrase instead of the more common accusative or the genitive which is found with the substantive phrase, cf. the construction as possessor of the 'good health' in (17)-(18). Not surprisingly perhaps, confusion between the various ways of constructing these formulaic phrases could lead to case interchange (22). ${ }^{48}$

(22) P.Berl.Zill. 11, 3-4 (Egypt, III CE)

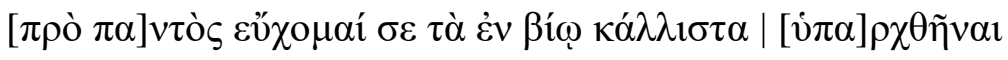

'Before all, I pray that the best things in life are yours.'

The scribe might have started this phrase with the common $\varepsilon$ v̋ $\chi \mu \alpha i$ $\sigma \varepsilon$ and infinitive phrase in mind, but finished the sentence with the predicative possession construction that would have required a dative pronoun at the beginning of the phrase (ed.pr. n. to 1. 2). This provides a good example of case interchange due to phraseological variation.

Most of the above mentioned phrases are commonly attested throughout the Roman period. A different formulation of the health wish appears in private letters from the fourth century onwards (Koskenniemi 1956: 187). In this new phrase the sender expresses the hope that the

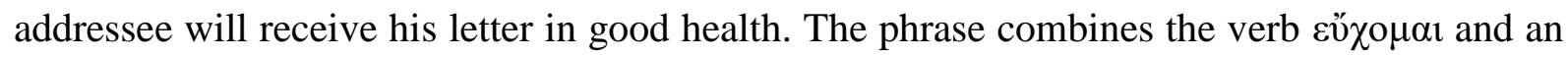

\footnotetext{
${ }^{47}$ Phrase-internal analogical formation could also cause case interchange, e.g. O.Claud. II 238, 2-3 (TM 29661;

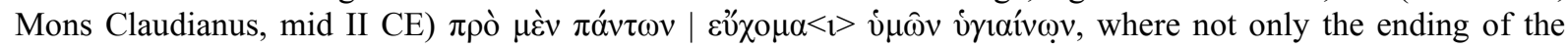

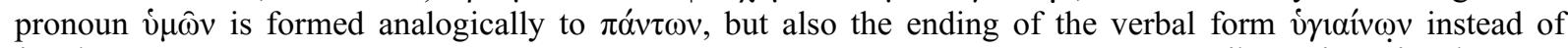

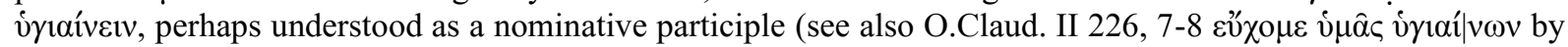
the same scribe).

${ }^{48}$ A possible confusion with the formulation of the beneficiary as possessor might be found in SB X 10279, 2-3

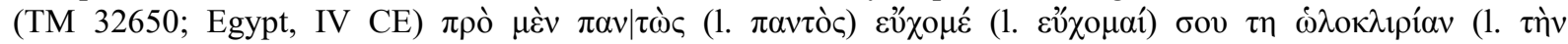

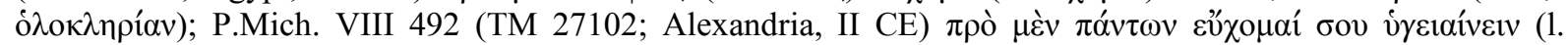

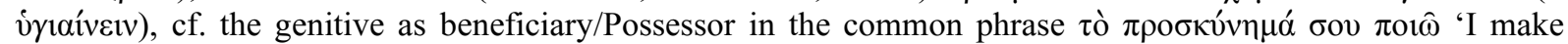

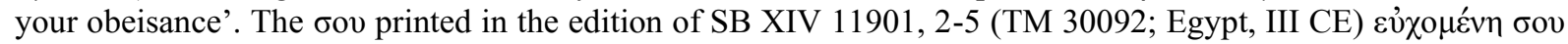

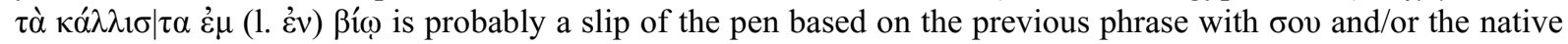
language of the editor (Parásogglou 1973: 280-281): the papyrus clearly reads oor (based on photo).
} 
accusative and infinitive construction, while the wishes for health and well-being are constructed as participial complements to the accusative pronoun (23).

(23) P.Oxy. LVI 3860, 2-4 (Oxyrhynchos, late IV CE)

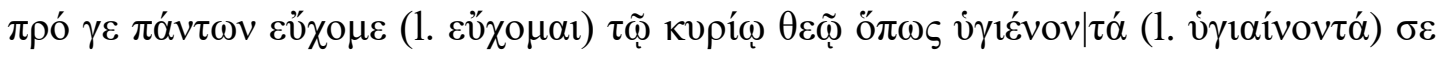

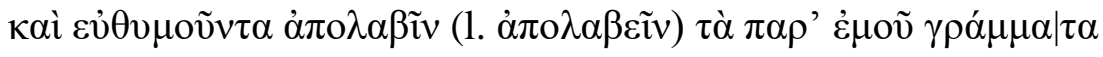

'Before all, I pray to the lord god that you may receive the letter from me in good health and good spirits.'

In principle, it might be ambiguous whether the addressee or the letter should be understood as the subject of the infinitive (P.Oxy. LVI 3860, n. to 1. 2-3; Koskenniemi 1956: 135-137). Based on the meaning of the verb $\alpha \dot{\pi} \mathrm{\alpha} \lambda \alpha \dot{\alpha} \beta \alpha \nu \omega$ "einen Besucher empfangen", "Geld oder Sachen erhalten" (Preisigke s.v.), we consider it more likely that the subject is the person receiving the letter (see also n. 64). ${ }^{49}$ Case interchange with the dative case is also found in this formula (24).

(24) P.Abinn. 31, 4-5 (Arsinoites, ca. 346 CE)

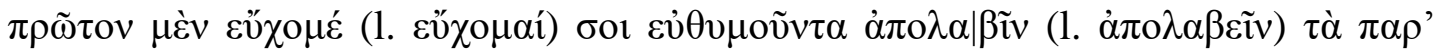
$\dot{\varepsilon} \mu[0] \tilde{v} \gamma \rho \alpha ́ \mu \mu \alpha \tau \alpha$

'First, I pray that you may receive the letter from me, being in good spirits.'

In (24), only the personal pronoun is written in the dative case, while the participle connected to the pronoun is in the accusative case, cf. also example (1). ${ }^{50}$ Most interestingly, the new formula is also attested in a variant formulation with the dative pronoun (25) during the fourth century.

(25) P.NYU I 25, 3-4 (Karanis, IV CE)

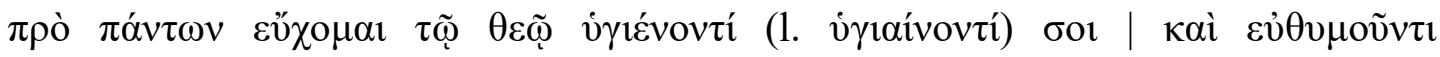

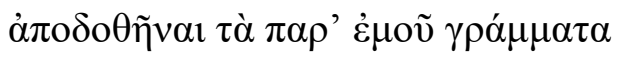

'Before all, I pray to the god that the letter from me is delivered to you being in good health and good spirits.'

\footnotetext{
${ }^{49}$ See also P.Bour. 25, 4-6 (TM 32904; Syria, IV-V CE); P.Oxy. LVI 3859, 3-5 (TM 33600; Oxyrhynchos, IV

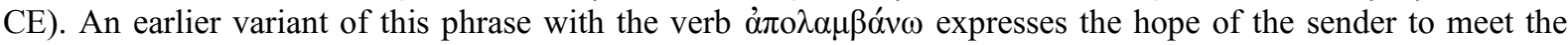

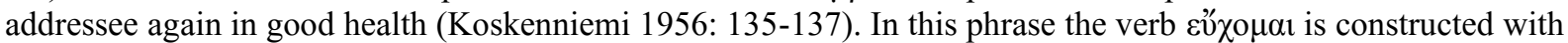
a co-referential infinitival complement in which the accusative pronoun functions as the object of the verb and the verb $\dot{\alpha} \pi \circ \lambda \alpha \mu \beta \alpha{ }^{\alpha} \omega$ means 'to receive' in the sense of 'to meet', cf. Preisigke s.V. "mit jmd zusammentreffen",

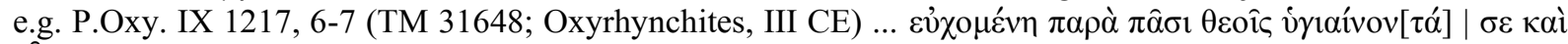

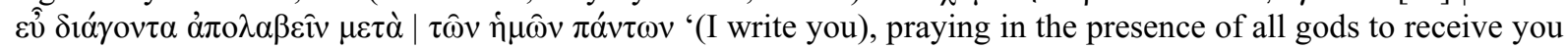
among us all being in good health and in a good condition'.

${ }^{50}$ The preference for the accusative participle in examples (1) and (24) next to the dative pronoun, might have

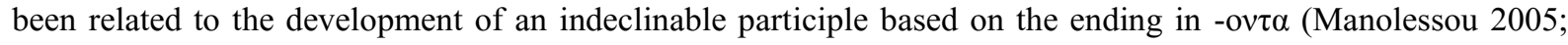
Horrocks 2010: 181-183).
} 
In this variant formula the passive infinitive of $(\dot{\alpha} \pi \mathrm{o}) \delta i \delta \omega \mu$ ' to give, to deliver to' is constructed with the letter as the subject in the accusative and the dative pronoun for the Recipient of the letter. ${ }^{51}$ The two formulas in (23) and (25) are very similar, both in contents and construction. Kim (2011: 148) discusses them together as one category and notes: "Der Adressat in der Participialkonstruktion steht entweder im Akkusativ $(\sigma \varepsilon)$ oder im Dativ ( $\sigma 01)$ "'. These close phraseological parallels could explain the case interchange of the personal pronoun and/or participles, cf. (24) and (26). ${ }^{52}$

(26) P.Oxy. XLVIII 3396, 3-4 (Oxyrhynchos, 330-385 CE)

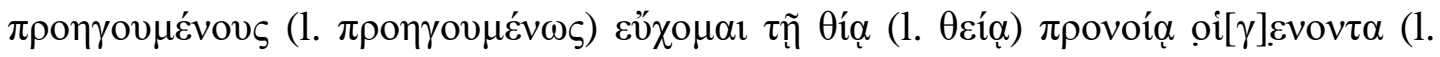

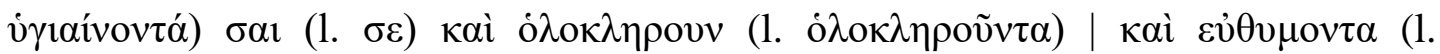

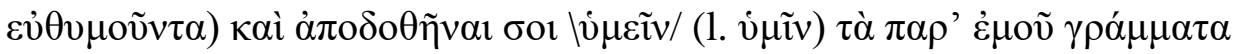

'First, I pray to the divine providence that you (sg.) are in good health and thriving and in good spirits and that the letter from me is delivered to you (pl.).'

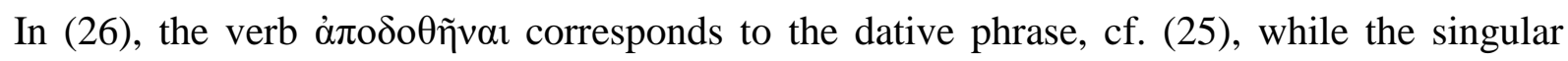
pronoun $(\sigma \alpha 1$ for $\sigma \varepsilon)$ and the participles (oi $[\gamma] \varepsilon v o v \tau \alpha$, ó $\lambda \circ \kappa \lambda \eta \rho \circ v v<\tau \alpha>$ and $\varepsilon \dot{v} \theta v \mu o v \tau \alpha)$ are similar to the accusative phrase, cf. (23). The scribe might have started the accusative phrase

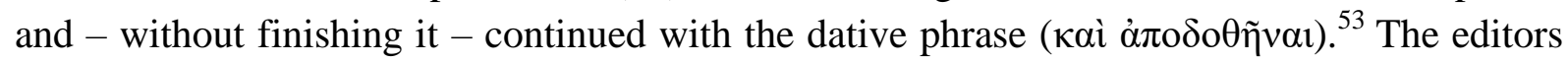
read an eliminated accusative pronoun $\sigma \alpha \iota$ (for $\sigma \varepsilon$ ) after $\dot{\alpha} \pi \circ \delta \circ \theta \tilde{\eta} v \alpha l$, but the reading of a dative pronoun $\sigma 01$ seems better to us (based on photo). ${ }^{54} \mathrm{~A}$ dative plural pronoun (i $\mu \varepsilon \tilde{\mathrm{i} v}$ for $\dot{v} \mu \mathrm{iv})$ was added above the line, corresponding to the two addressees of this letter. The dative

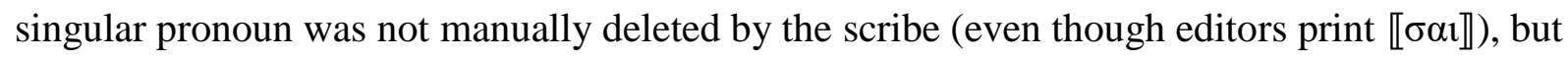
the plural pronoun is written directly above it to indicate a correction. As the correction $\dot{v} \mu \varepsilon \tilde{i} v$

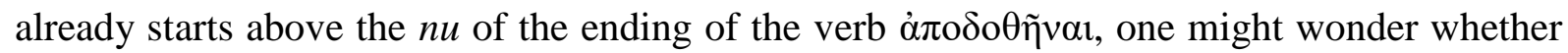

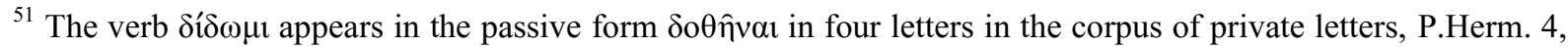
4-6 (TM 21123; Hermopolis, ca. 317-323 CE); P.Oxy. XII 1593, 1-3 (TM 33662; Oxyrhynchites; IV CE); SB XIV 11588, 2-6 (TM 32936; Egypt, late IV CE) and P.Herm. 5, 3-4 (TM 21124; Hermopolis; ca. 317-323 CE).

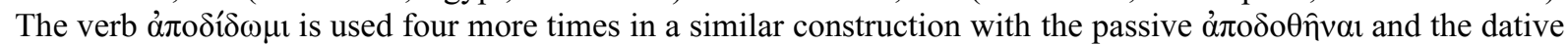
бo1: P.NYU I 25, 3-4 (TM 33591; Karanis, IV CE); P.Neph. 1, 4-6 (TM 33555; Alexandria; IV CE); P.Neph. 10, 3-6 (TM 33563; Alexandria, 350-370 CE); P.Princ. II 101, 4-6 (TM 32797; Egypt, IV CE); SB XXVI 16716, 4-8 (TM 97320, Egypt, IV CE); P.Oxy. XLVIII 3396, 3-4 (TM 33708; Oxyrhynchos, 330-385 CE). A similar

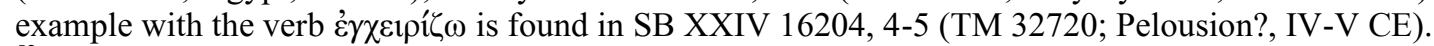

${ }^{52} \mathrm{Cf}$. the datives and accusatives in two 'accusative' formulas with $\alpha$ to $\lambda \alpha \beta \varepsilon i v$ : P.Oxy. XIV 1680, 3-4 (TM

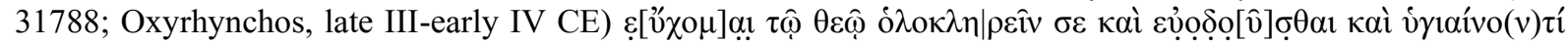

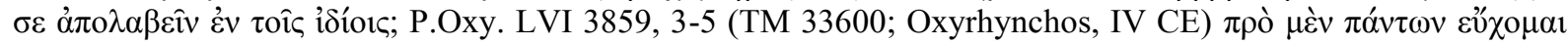

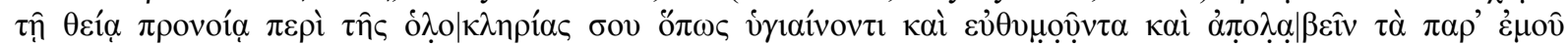

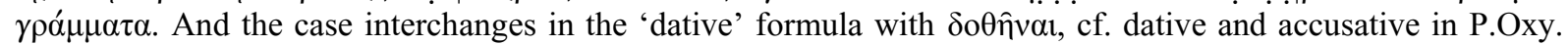

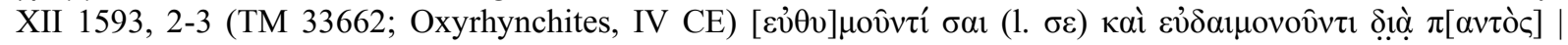

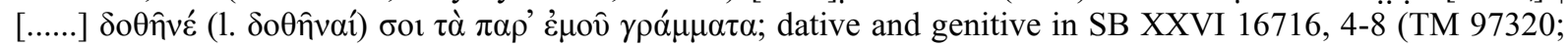

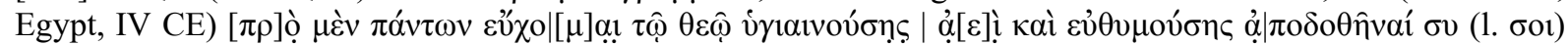

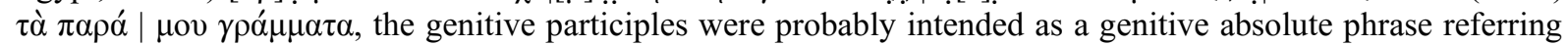
to the addressee (cf. ed.pr. n. to 1. 1-8 and 3.2.3).

${ }^{53}$ The contamination of the two formulas is noticed in the ed.pr., n. to 1. 3-4, but the אaí connecting the two phrases was eliminated in the reading of the edition in an attempt to regularize one of them.

${ }^{54}$ Ed.pr. $\sigma \sigma \alpha 1 \rrbracket$. The small sign is connected at the top to the preceding sigma and the following iota. This corresponds better to the omicron (see for example the connections of the omicron in i $\mu \varepsilon \dot{\sigma} \sigma o v \varsigma, 1$. 18), because the alpha generally connects on the lower left side to preceding sign and with a curl on the top to the following sign in this hand.
} 


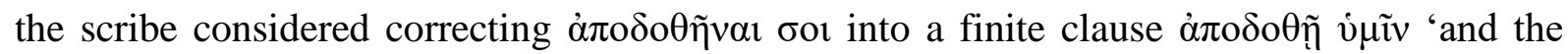
letter is given to you'. However, making the second part of the clause independent from

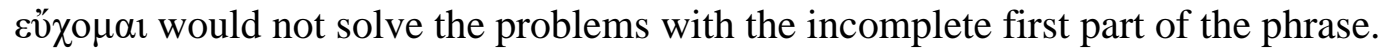

It is remarkable that whereas the earlier dative alternatives for the initial health wish (17)(20) and the dative interchanges for the accusative pronoun, were considerably less frequent than the common accusative and infinitive formula, the new early Byzantine formula with the dative case (25) seems as frequently attested as the accusative variant of this phrase.

\subsubsection{Semantics and syntax}

The dative and accusative pronouns in the Roman formula usually function as the Beneficiary of the health wish. It is not difficult to understand why a scribe would be tempted to mark a Beneficiary of a wish or prayer in the dative case. ${ }^{55}$ In the early Byzantine formula, both the dative and the accusative are used to mark the Recipient of the letter. With respect to semantics, the dative case seems a natural choice to denote the Beneficiary of the wish and Recipient of the letter in those phrases. The question, therefore, comes down to syntax: what happened to the accusative and infinitive construction? According to Horrocks (2010: 180), the accusative and infinitive is only preserved in formulaic phrases, e.g. the health wish and

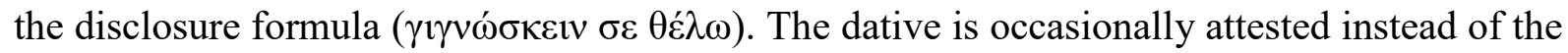
accusative in the disclosure formula as well (27). ${ }^{56}$

(27) SB XVIII 13593, 6-7 (Egypt, III-IV CE)

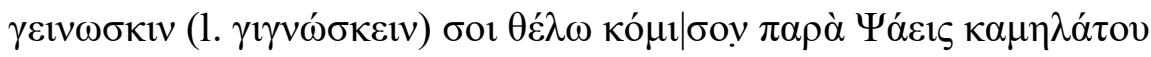

'I want you to know: bring from Psais the camel-driver ...'

In this formula, the dative case can also be understood semantically as the Beneficiary or addressee of the disclosure of information, i.e. 'to give knowledge, to inform' ${ }^{57}$ In his study on verbal complementation in Roman and Byzantine papyri, James (2007: 57, 104-105, 108110) concluded that the accusative and infinitive construction as complement to verbs of perception, cognition and declaration is rare in personal letters, with the exception of certain verbs such as $\mu \alpha v \theta \alpha \dot{v} \omega$ and $\gamma \mid \gamma v \omega \dot{\sigma \kappa} \omega$ (which occur in fixed phrases). The construction remained in use in formulaic contexts in legal administrative documents, but even there it is not found with verbs of declaration anymore during the Byzantine period (James 2007: 110121). Hence, the use of the dative in epistolary phrases might be related to the decline of the accusative and infinitive construction in the written language at this time. ${ }^{58}$ The use of a

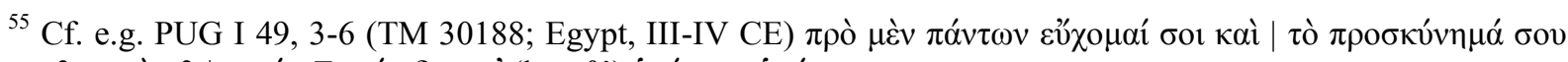

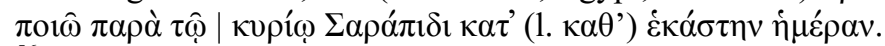

${ }^{56}$ In this letter, the dative is also used for the Addressee in the salutation formula, see example (5). Other examples of the dative in the disclosure formula are P.Oxy. XIV 1680, 16-17 (TM 31788; Oxyrhynchos, late III-

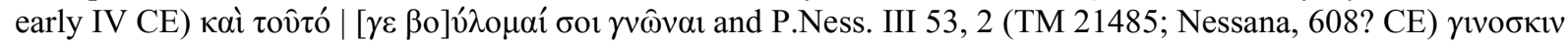

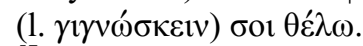

57 The accusative and infinitive construction with a verb of desire becomes more common than the previous imperative of a verb for knowing in the opening of a letter around 100 CE (Porter and Pitts 2013).

${ }^{58}$ Nine out of the 26 texts with a dative instead of accusative in the health wish contain a correct accusative and

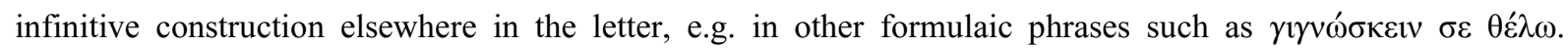


dative and infinitive clause with disjoint reference (subject of the infinitive is not the same as the subject of the finite verb) instead of an accusative and infinitive construction is also attested outside of formulaic phrases from the fourth century onwards (28).

(28) P.Abinn. 29, 19-21 (TM 10026, Arsinoites, ca. 346 CE)

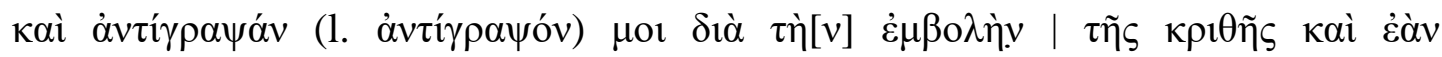

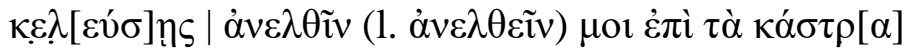

'and write back to me about the shipment of barley and (write) whether you order me to go up to the camp'

The dative pronoun was corrected into an accusative in the ed.pr., because an accusative and infinitive construction is expected after the verb $\kappa \varepsilon \lambda \varepsilon v ́ \omega$ (cf. LSJ s.v.). However, if the dative can be understood as the Addressee of the verb $\kappa \varepsilon \lambda \varepsilon v \omega \omega$ 'to order' with a disjoint infinitival complement, there is no need to correct the pronoun here. Verbs of ordering like $\kappa \varepsilon \lambda \varepsilon v i \omega$ are usually constructed with an accusative Addressee in Classical Greek and only rarely with a dative (Kavčič 2005: 129-130; Riaño 2006: 503-504). ${ }^{59}$ This seems to change in the early Byzantine period (Kavčič 2005: 129-134). Comparison of fifth century literary sources shows that the use of the dative and infinitive after $\kappa \varepsilon \lambda \varepsilon v ́ \omega$ can be considered a stylistically neutral variant of the accusative and infinitive construction at that time (Kavčič 2005: 134). In the papyri, a change can already be observed before the fifth century. The verb $\kappa \varepsilon \lambda \varepsilon v ́ \omega$ seems to govern an accusative Addressee in Ptolemaic and early Roman papyri, but take a dative pronominal complement in the late Roman and Byzantine period (after $200 \mathrm{CE}$ ). ${ }^{60}$ This could provide another instance of the tendency to replace the accusative Addressees of communication verbs by the dative case, as we also observed in section 3.1.3. ${ }^{61}$ The use of the dative with an infinitival complement with the verb $\kappa \varepsilon \lambda \varepsilon v ́ \omega$, however, does not stand on its own. Similar occurrences of the dative instead of the accusative with an infinitive phrase are attested in other papyrus documents from the Roman and Byzantine periods. ${ }^{62}$ This suggests

Generally, paratactic construction seems to gain popularity, e.g. oî̉ $\varepsilon \varsigma \varsigma$ ö $\tau$ in O.Did. 350, 4 (TM 144911; Didymoi, before ca. 77-92 CE).

${ }^{59}$ Attestations of $\kappa \varepsilon \lambda \varepsilon v i \omega$ with a dative case are attested in several post-Classical Greek sources (see references in Kavčič 2005: 130,134), and seem especially common from the fifth century onwards.

${ }^{60} \mathrm{~A}$ PN search for the verb $\kappa \varepsilon \lambda \varepsilon v ́ \omega$ with accusative pronoun $\mu \varepsilon$ yields mostly texts from the Ptolemaic and early Roman period (until $200 \mathrm{CE}$, one text from the IV century CE), while $\kappa \varepsilon \lambda \varepsilon v ́ \omega$ with $\mu \mathrm{ot}$ is attested once in the Ptolemaic period and otherwise only in texts after 200 CE, e.g. with dative without infinitive in P.Neph. 10, 18-

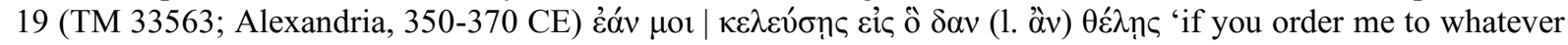

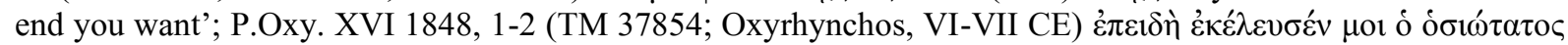

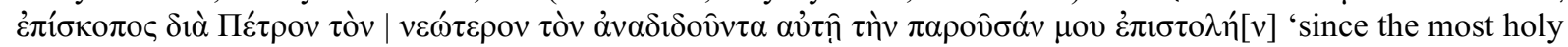
bishop has given me an order on behalf of Peter the younger, the bearer of the present letter'.

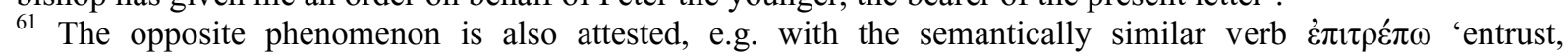
command' which usually takes a dative complement, e.g. in P.Oxy. LIX 4005, 8 (TM 36848; Oxyrhynchos, VI

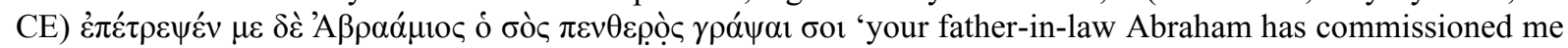
to write to you'.

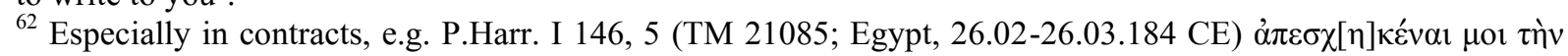

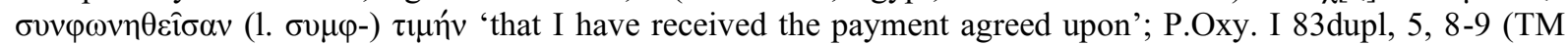

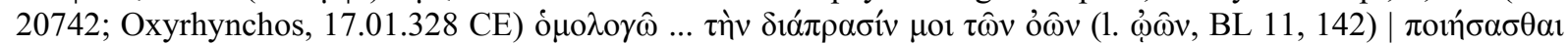
'I agree ... that I make the sale of the eggs'; P.Ness. III 19, 3-4 (TM 21466; Nessana, 18.08.548 CE)

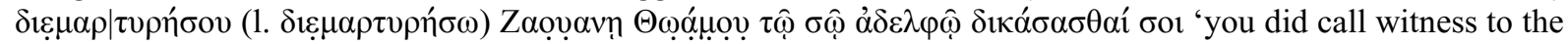
fact that you bring suit against your brother Za'wān son of Thomas'; BGU XIX 2834, 8-10 (TM 91744; 
that the use of the dative case in these constructions may be related to the decline of the disjoint infinitival construction during this period (cf. James 2007). In the light of these developments, it is, therefore, not surprising that the dative as Beneficiary or Addressee is sometimes used in epistolary phrases formerly taking an accusative and infinitive construction.

Even though the new Byzantine phrases use a dative pronoun to mark the Recipient, they are initially still constructed with an accusative and infinitive clause (cf. 3.2.2), while the first signs of a transition towards finite clause complementation are apparent (Joseph 2002; James 2007). Intermediate stages of the development towards finite clause complementation can be observed in the phraseological variation in these epistolary formulas. In (23), the conjunction ö $\pi \omega \varsigma$ was added to the accusative and infinitive construction, but there are also examples of complete finite complementation in the dative formula (29). ${ }^{63}$

(29) P.Neph. 10, 3-6 (Alexandria, 350-370 CE)

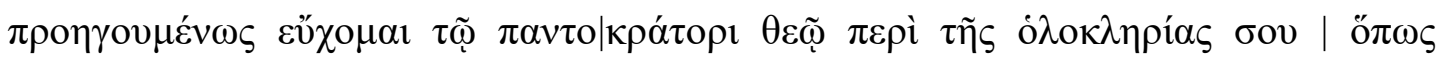

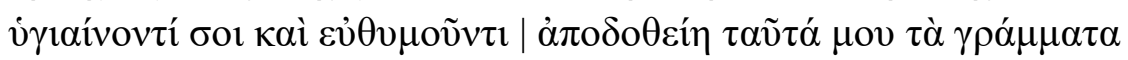

'First, I pray to the almighty God for your health so that this letter of mine is delivered to you being in good health and good spirits.'

The replacement of the accusative and infinitive construction by finite complementation did not make the construction of these particular phrases less problematic. Scribes seem to struggle with the possibilities to formulate the phrase, in particular the accusative variant. Confusion about the construction might have led to the mixed formulas in (30) and (31). Both (30) and (31) start with a prayer for health in the substantive form (cf. 29, and examples 17-18 in 3.2.2) and continue with the later form of the health wish containing a finite clause about the letter being received.

(30) P.Lips. I 111, 3-5 (Egypt, IV CE)

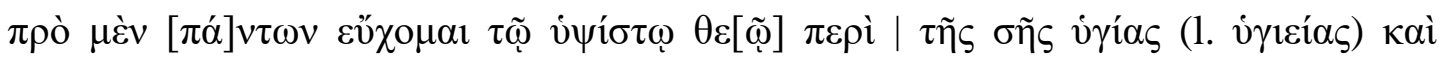

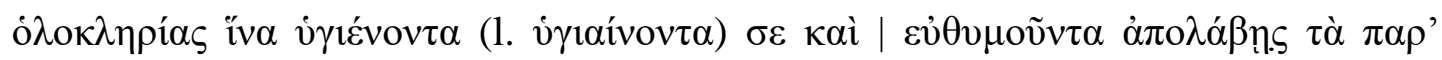
$\dot{\varepsilon} \mu о \tilde{v} \gamma \rho \alpha ́ \mu \mu \alpha \tau \alpha(B L 1,214)$

'Before all, I pray to the highest god for your health and well-being, so that you may receive the letter from me being in good health and good spirits.'

The letter in (30) is written in a practiced hand and contains few deviations (the salutations and closing formula contain the expected accusative pronoun $\sigma \varepsilon$ ). The phrase in (30) in its current form is most similar to the accusative and infinitive clause with an additional conjunction, cf. ö $\pi \omega \varsigma$ in (23), but after the conjunction ǐva in (30) a finite verb is found, read

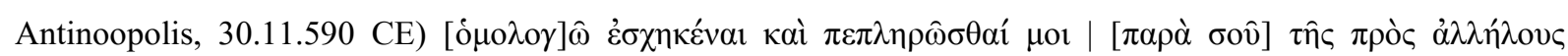

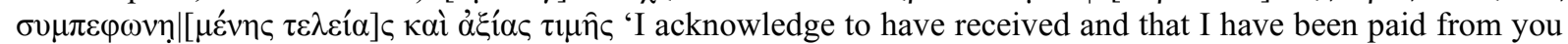
the complete and proper price jointly agreed upon'. In most of the above examples the dative replacement of the accusative subject of the infinitive construction can be understood as the Recipient or Beneficiary of the event.

${ }^{63}$ See also Ljungvik 1932: 46-47 about ö $\pi \omega \varsigma$ with infinitive. 


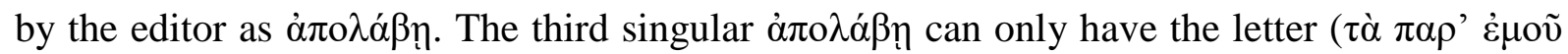
$\gamma \rho \alpha ́ \mu \mu \alpha \tau \alpha)$ as subject. Mitteis translates, therefore, in the ed.pr.: "daß dich mein Schreiben gesund und wohlauf antrifft". This interpretation is also favoured by Naldini (1968: 247) "perché la mia lettera ti trovi sano e sereno", following the interpretation by Koskenniemi (1956: 135-137). If the scribe indeed intended the letter as the subject of the verb in this case, it could have been due to the confusion between the subject and object of the accusative and infinitive construction or by comparison to the dative formula in which the letter functions as the subject of the passive infinitive of the verb 'to give' (29). However, it has not been noticed in previous accounts of this formula that it is the second person singular form $\dot{\alpha} \pi \mathrm{o} \lambda \alpha \beta_{n} \varsigma_{\varsigma}$ that is attested in almost all finite variants of this formula (see n. 66). Based on this occurrence of a second person singular verb in parallel (finite) phrases, it could also be concluded that the Addressee is the expected subject of the accusative and infinitive construction in this formula (against Koskenniemi 1956: 137; Naldini 1968: 100, 247) ${ }^{64}$ Hence, we would also expect a second person singular verb form $\alpha \dot{\alpha} \mathrm{o} \lambda \alpha \beta_{\mathfrak{n}} \mathrm{s}$ in (30). Final sigma is frequently omitted in papyri (Gignac 1976: 124-126), so it might be possible to read $\alpha \dot{\alpha} \mathrm{o} \lambda \dot{\alpha} \beta \eta<\varsigma>$ here (as also proposed in P.Oxy. XIV 1683, n. to 1. 6, and Ghedini 1923: 213). However, based on the

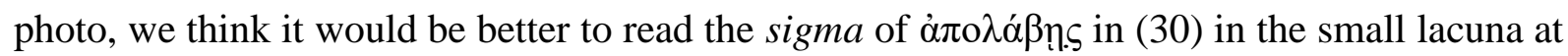
the end of the verb (some traces of the upper and lower bars of the sigma might be preserved at the right edge of the lacuna). This solves the issue of the interpretation of the subject of the clause.

Furthermore, Naldini (1968: 247) argues that the accusative case of the complement is problematic for the interpretation with a second person singular finite verb. In (31), the second person singular verb $\alpha \dot{\alpha} \mathrm{\lambda} \lambda \alpha \beta_{\eta} \varsigma$ is also attested together with a pronoun and participles in the accusative and dative cases.

(31) P.Oxy. XIV 1683, 4-8 (Oxyrhynchos, late IV)

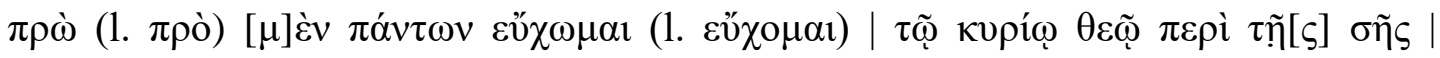

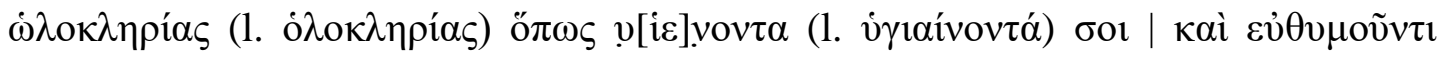

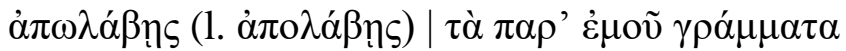

'Before all, I pray to the lord god for your well-being so that you may receive the letter from me being in good health and spirits.'

\footnotetext{
${ }^{64}$ Naldini (1968: 100) notes that the accusative pronoun in the earlier variant of this phrase (without a letter

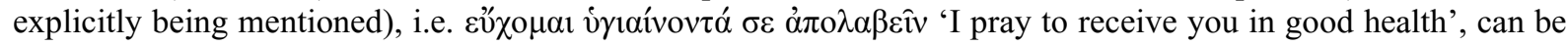
interpreted both as the object as well as the subject of the infinitive with 'the letter' as an implicit object (Koskenniemi 1956: 136; Kim 2011: 148, n. 300). We think that it is important to distinguish between the earlier variant constructed as a co-referential infinitive with the accusative pronoun as object 'I pray to receive you' for which Koskenniemi (1956: 136-137) rightly argues for a meaning of "Zusammentreffen", and the later

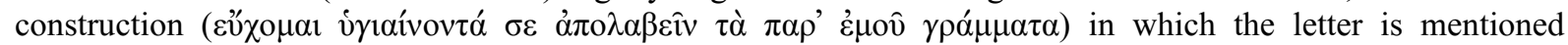
explicitly ('I pray that you receive the letter') which seems to us primarily concerned with the arrival of the letter. The difference can be observed in the finite formulations of both phrases, cf. P.Lips. I 110, 6-8 (TM

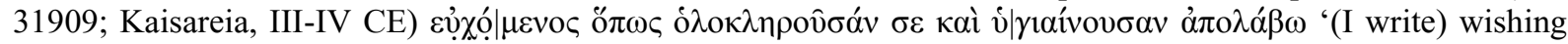
that I receive/meet you, thriving and being in good health' vs. P.Batav. 21, 3-7 (TM 37506; Oxyrhynchos, V CE)

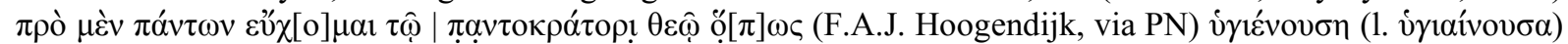

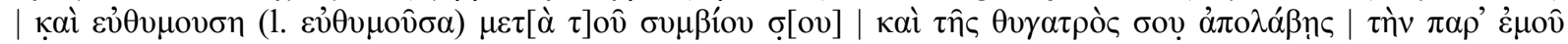

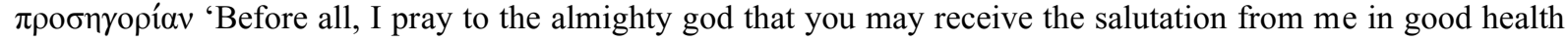
and good spirits with your husband and your daughter.'
} 
This letter contains many orthographic deviations and several case interchanges. ${ }^{65}$ To solve the discrepancy between the second person singular finite verb and the dative ( $\sigma 01$,

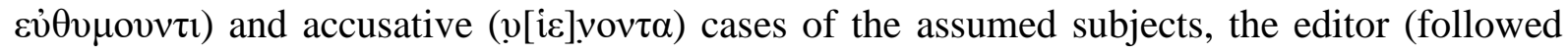
by Ghedini 1923: 251; Kim 2011: 150) regularizes the dative pronoun $\sigma 01$ into a (superfluous) nominative pronoun $\sigma v$ and the participles into the nominative singular feminine, resp.

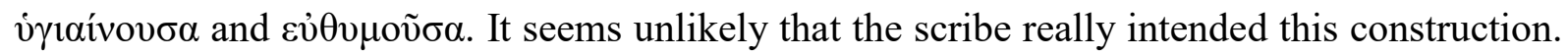
The formula with the finite verb $\dot{\alpha} \pi \circ \lambda \alpha \beta_{n} \varsigma$ is commonly attested in the IV-VI centuries, but only rarely are co-referential pronominal and participial complements found in the congruent nominative case. ${ }^{66}$ Based on the currently available attestations, the construction as a genitive absolute clause seems most common. ${ }^{67}$ That is not to say that the pronoun and participles in (31) should rather be regularized into the genitive case. Instead, the formulation in (31) attests of the confusion between three phraseological variants of the health wish (Naldini 1968: 273), i.e. the accusative and infinitive constructions with the accusative or dative pronoun as Recipient and the finite clause construction.

Due to the high amount of phraseological variation in other letters from the same period, it seems impossible to say which - if any - formulation was commonly intended. Consistent regularization of these phrases does not only seem difficult, but, more importantly, it obscures the linguistic reality of the formulation in these papyri: the various attempts to convert the no longer understood accusative and infinitive construction into a finite clause. The new formulation often still reflects the remains of the old - but perhaps still taught - epistolary formula in which the Beneficiary of the wish and the Recipient of the letter were constructed in the accusative instead of the semantically more transparent dative case.

\section{Conclusion and discussion}

Dative for accusative interchange is found especially in two types of epistolary phrases, i.e.

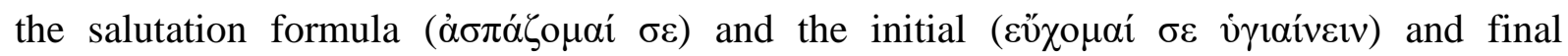

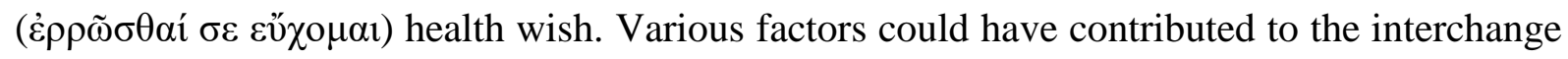
of cases in these contexts. Some of the papyrus letters seem to be written by scribes with an Egyptian background. Second language learning may explain some problems with Greek case inflection. However, the dative case in these phrases is also attested outside of Egypt. In fact,

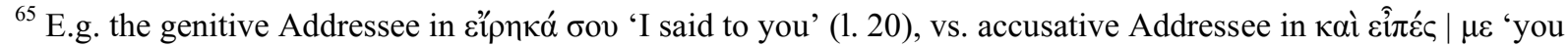
said to me' (11. 22-23) and accusative Recipient in $\sigma \varepsilon \delta[$ [ $\delta] \omega$ 'I give it to you' (1. 24), see Horrocks 2010: $183-$ 185.

${ }^{66}$ The second person singular finite verb $\alpha \dot{\pi} \mathrm{\alpha} \lambda \alpha \beta^{\prime} \varliminf_{\varsigma}$ is found in this formula with the pronoun and participles in the genitive in P.Oxy. LVI 3863, 5-8 (TM 35474; Oxyrhynchos, V CE); P.Ross.Georg. III 10, 4-6 (TM 32908 ; Egypt, second half IV-V CE); P.Haun. II 25, 4-7 (TM 32377; Egypt, IV-V CE); and perhaps P.Wash.Univ. I 35, 2 (TM 32572; Oxyrhynchos, IV-V CE, see reading and supplement in BL 11, 289); with participles in the nominative in P.Batav. 21, 3-7 (TM 37506; Oxyrhynchos, V CE) and perhaps P.Köln II 111, 2-3 (TM 35436; Egypt, V-VI CE); pronoun and participles in the dative and the accusative in P.Abinn 22, 3-5 (TM 10022; Alexandria, after 351 CE, BL 8, 1) and P.Oxy. LIX 4000, 3-4 (TM 33121; Oxyrhynchos, IV CE); pronoun and participles in the genitive and the accusative in P.Oxy. LVI 3864, 5-8 (TM 35475; Oxyrhynchos, V CE); without pronoun and participles in P.Congr.XV 20, 3-5 (TM 32157; Oxyrhynchos, late III-early IV CE). If the identification of the hand by Gonis (2000: 184) is correct, P.Haun. II 25 and P.Oxy. LVI 3864 are written by the same scribe, who wrote the complements in the genitive, resp. in the accusative and the genitive.

${ }^{67}$ The replacement of congruent participles by the genitive absolute construction might be an intermediary stage of the development towards the Modern Greek gerund (Mandilaras 1983: 369; Manelessou 2005: 245).
} 
many of the cognitive processing mechanisms responsible for scribal variation may have been similar for scribes regardless of their native language.

The phonetic similarity of the vowels of the dative $(\sigma \circ 1)$ and accusative $(\sigma \varepsilon)$ singular clitic pronouns may have created the circumstances for the confusion of cases. When the case form could not be distinguished clearly in the pronunciation of the phrase, the end result depended on the scribe's education and his knowledge of the norms of the language. Variation may be especially common in fixed phrases, because scribes attempted to reproduce conservative features, but struggled to understand the old-fashioned constructions in epistolary formulas.

In the salutation formula, the occasional use of a dative Addressee could be explained by analogical overextension from the more productive category of communication verbs taking a dative complement (speaking, writing) to the category of verbs taking an accusative Addressee (asking, greeting). The decline of the accusative and infinitive construction could be one of the reasons why the accusative subject of disjoint infinitives is sometimes replaced by the dative Beneficiary in health wishes. By the end of the Roman period, even in formulaic phrases, a transition towards finite clause complementation is apparent. Mixed phrases with accusative and dative pronouns (and participles) are frequently found as well as combinations of constructions from the old and new formulaic phrases.

Due to the high amount of phraseological variation in papyrus letters from the Byzantine period, it is difficult to conclude which formulation was commonly intended. The phonetic spellings and the contaminations of the various possible constructions reflect the difficulties of the scribes to reconstruct the conservative epistolary phrases correctly. Among others, the variation might reveal changes in the language. Structural changes include the alternation of dative and accusative for the Addressee of communication verbs and the replacement of the accusative and infinitive construction by finite complementation. The decline of the dative case might have enhanced the overextension of the dative case in these instances. The dative case seems to be the preferred alternative to denote the Addressee of greeting, Beneficiary of the health wish and the Recipient of a letter in epistolary phrases from the Roman and Byzantine periods.

\section{References}

Adams, James N. 2013. Social Variation and the Latin Language. Cambridge: Cambridge University Press.

Bagnall, Roger S. 1999. "Eirene to Epaphrys: P.Yale I 77 revised." Chronique d'Égypte 74: 109-117.

Bagnall, Roger S. and Raffaella Cribiore. 2006. Women's Letters from Ancient Egypt, 300BC-AD800. Michigan: University of Michigan Press.

Barðdal, Jóhanna and Leonid Kulikov. 2009. "Case in decline”. In Andrej Malchukov and Andrew Spencer (eds.) The Oxford Handbook of Case, 470-478. Oxford: Oxford University Press.

Bell, Sir Harald. 1950. “A Happy Family.” In Aus Antike und Orient. Festschrift Wilhelm Schubart zum 75. Geburtstag, edited by Siegfried Morenz, 38-47. Leipzig: Harrassowitz.

Biedendorf-Ziehner, Anneliese 1983. Untersuchungen zum koptischen Briefformular unter Berücksichtigung ägyptischer und griechischer Parallelen. Würzburg: Zauzich.

Brixhe, Claude. 2010. "Linguistic Diversity in Asia Minor during the Empire: Koine and Non-Greek Languages." In A Companion to the Ancient Greek Language, edited by Egbert J. Bakker, 213-252. Oxford: Wiley-Blackwell.

Bülow-Jacobsen, Adam. 2001. "The Pronunciation of Greek in the Ostraca from the Eastern Desert." In Atti del XXII Congresso Internazionale di Papirologia, Firenze 23-29 agosto, 1998, 157-162. Firenze: Istituto Papirologico G. Vitelli.

Bybee, Joan. 2010. Language, usage and cognition. Cambridge: Cambridge University Press.

Cromwell, Jennifer. 2010. "Palaeography, scribal practice and chronological issues in Coptic documentary texts." Journal of the American Research Center in Egypt 46: 1-16. 
Crum, Walter Ewing. 1939. A Coptic Dictionary. Oxford: Clarendon.

Depauw, Mark. 2006. The Demotic Letter: A study of epistolographic scribal traditions against their intra- and intercultural background. Sommerhausen: Zauzich.

Depauw, Mark and Joanne Stolk. 2015. "Linguistic Variation in Greek Papyri. Towards a New Tool for Quantitative Study.” Greek Roman and Byzantine Studies 55: 196-220.

Dickey, Eleanor. 2010. "Latin influence and Greek request formulae." In The Language of the Papyri, edited by Trevor V. Evans and Dirk Obbink, 208-220. Oxford: Oxford University Press.

Elspass, Stephan .2012. The use of private letters and diaries in sociolinguistic investigation. In HernándezCampoy, J. M. \& J. C. Conde-Silvestre, The Handbook of Historical Sociolinguistics, 156-169. Chichester: Wiley-Blackwell.

Evans, Trevor. 2012. "Linguistic and Stylistic Variation in the Zenon Archive." In Variation and Change in Greek and Latin, Papers and Monographs of the Finnish Institute at Athens 17, edited by Martti Leiwo, Hilla Halla-aho and Marja Vierros, 25-42. Athens: Finnish Institute at Athens.

Exler, F.X.J. 1923. The Form of the Ancient Greek Letter. A Study in Greek Epistolography, Washington D.C.: Catholic University of America.

Ghedini, Giuseppe. 1923. Lettere cristiane dai papiri greci del III e IV secolo. Milano: Vita e Pensiero.

Gignac, F.T. 1976. A Grammar of the Greek Papyri of the Roman and Byzantine Periods. Vol. 1: Phonology. Milano: La Goliardica.

Gonis, Nikolaos. 2000. "Notes on Oxyrhynchus Papyri II.” Zeitschrift für Papyrologie und Epigraphik 129: 183184.

Halla-aho, Hilla. 2008. "The non-literary Latin letters: A study of their syntax and pragmatics." PhD diss., University of Helsinki.

Halla-aho, Hilla. 2010. "Linguistic varieties and language level in Latin non-literary letters." In The Language of the Papyri, edited by Trevor V. Evans and Dirk Obbink, 171-183. Oxford: Oxford University Press.

Holton, David and Io Manolessou. 2010. "Medieval and Early Modern Greek." In A Companion to the Ancient Greek Language, edited by Egbert J. Bakker, 539-563. Oxford: Wiley-Blackwell.

Horrocks, Geoffrey. 2007. "Syntax: From Classical Greek to the Koine." In A History of Ancient Greek: From the Beginnings to Late Antiquity, edited by A.-F. Christides, 618- 631. Cambridge: Cambridge University Press.

Horrocks, Geoffrey. 2010. Greek: A History of the Language and its Speakers. Second Edition. Chichester: Wiley-Blackwell.

Humbert, Jean. 1930. La disparition du datif en grec (du Ier au Xe siècle). Paris: Champion.

James, Patrick. 2007. "Retention and retreat: complementary participles and infinitives with verbs of perception and declaration in the Roman and Byzantine documentary papyri." PhD diss., Cambridge University.

Joseph, Brian. 2002. "On Some Control Structurees in Hellenistic Greek: A Comparison with Classical and Modern Greek." Linguistic Discovery 1.1.

Kapsomenakis, Stylianos G. 1938. Voruntersuchungen zu einer Grammatik der Papyri der nachchristlichen Zeit. [Münchener Beiträge zur Papyrusforschung und antiken Rechtsgeschichte 28]. Chicago: Ares Publishers.

Kavčič, Jerneja. 2005. The Syntax of the Infinitive and the Participle in Early Byzantine Greek. Ljubljana: Znanstveni inštitut FF (Razprave Filozofske fakultete).

Kim, Chinook. 2011. “,Grüße in Gott, dem Herrn”: Studien zum Stil und zur Struktur der griechischen christlichen Privatbriefe aus Ägypten.” PhD diss., University of Trier.

Koskenniemi, Heikki 1956. Studien zur Idee und Phraseologie des griechischen Briefes bis 400 n. Chr. Helsinki: Finnish Academy.

Lass, Roger 1997. Historical linguistics and language change. Cambridge: Cambridge University Press.

Leiwo, Martti. 2005. "Substandard Greek. Remarks from Mons Claudianus." In Ancient Greece at the Turn of the Millennium: Recent Work and Future Perspectives. Proceedings of the Athens Symposium 18-20 May 2001, Publications of the Canadian Archaeological Institute at Athens 4, edited by N.M. Kennell and J.E. Tomlinson, 237-261. Athens: The Canadian Institute in Greece.

Leiwo, Martti. 2012. "Introduction: Variation with Multiple Faces." In Variation and Change in Greek and Latin, Papers and Monographs of the Finnish Institute at Athens 17, edited by Martti Leiwo, Hilla Halla-aho and Marja Vierros, 1-11. Athens: Finnish Institute at Athens.

LSJ = Liddell, Henry George and Robert Scott, revised by Sir Henry Stuart Jones. 1996. A Greek-English Lexicon. Oxford: Clarendon.

Mandilaras, Basil G. 1973. The Verb in the Greek non-literary Papyri. Athens: Hellenic Ministry of Culture and Sciences.

Manolessou, Io. 2005. "From participles to gerunds". In Advances in Greek Generative Syntax: In honor of Dimitra Theophanopoulou-Kontou, edited by Melita Stavrou and Arhonto Terzi, 241-283. Amsterdam and Philadelphia: John Benjamins.

McColl Millar, Robert. 2015. Trask’s Historical Linguistics ${ }^{3}$. New York: Routledge. 
Moulton, James Hope and Nigel Turner. 1978. A Grammar of New Testament Greek. Edinburgh: T\&T Clark.

Naldini, Mario. 1968. Il cristianesimo in Egitto: lettere private nei papiri dei secoli II-IV. Firenze: Le Monnier.

Parássoglou, George M. 1973. "Five Private Letters from Roman Egypt." Hellenika 26: 271-281.

Parássoglou, George M. 1986. "Idiotikes epistoles apo te romaike Aigupto.” Hellenika 37: 260-279.

Paul, Michaela. 1992. "CPR VIII 52 komplettiert: Brief der Therpe an ihren Vater." Analecta Papyrologica 4: $75-78$.

Porter, Stanley E. and Andrew W. Pitts. 2013. "The Disclosure Formula in the Epistolary Papyri and in the New Testament: Development, Form, Function and Syntax." In The Language of the New Testament, edited by Stanley E. Porter and Andrew W. Pitts, 421-438. Leiden: Brill.

Preisigke, Friedrich. 1925. Wörterbuch der griechischen Papyrusurkunden. Berlin.

Riaño Rufilanchas, Daniel. 2006. El complemento directo en griego antiguo: Un estudio sobre los argumentos verbales de objeto en la prosa del griego antiguo. Madrid: Consejo Superior de Investigaciones Científicas.

Salonius, A.H. 1927. Zur Sprache der griechischen Papyrusbriefe. Helsinki: Akademiska Bokhandeln; Leipzig: Harrassowitz.

Sevdali, Christina and Elena Anagnostopoulou. 2013. "Indirect Object." Encyclopedia of Ancient Greek Language and Linguistics. Brill Online: http://referenceworks.brillonline.com/entries/encyclopedia-ofancient-greek-language-and-linguistics/indirect-object-COM_00000185.

Stolk, Joanne Vera. 2015. "Dative by Genitive Replacement in the Greek Language of the Papyri: A Diachronic Account of Case Semantics.” Journal of Greek Linguistics 15: 91-121.

Stolk, Joanne Vera. Forthcoming. "Dative and genitive case interchange in the Greek papyri from the Ptolemaic period". In Proceedings of the 27th International Congress of Papyrology, Warsaw 29.07-03.08.2013. Warsaw: Taubenschlag.

Thurn, Johannes (ed.) 2000. Ioannis Malalae Chronographia. Berlin and New York: De Gruyter.

Vierros, Marja. 2012. "Phraseological Variation in the Agoranomic Contracts from Pathyris." In Variation and Change in Greek and Latin, Papers and Monographs of the Finnish Institute at Athens 17, edited by Martti Leiwo, Hilla Halla-aho and Marja Vierros, 43-56. Athens: Finnish Institute at Athens.

Wagner, Esther-Miriam, Ben Outhwaite and Bettina Beinhoff. 2013. Scribes as agents of language change. Boston: De Gruyter Mouton.

White, John Lee. 1986. Light from Ancient Letters. Philadelphia: Fortress Press.

Wray, Alison. 2009. "Identifying formulaic language: persistent challenges and new opportunities." In Formulaic Language. Vol. 1: Distribution and Historical Change, edited by Roberta Corrigan, 27-51. Amsterdam and Philadelphia: John Benjamins.

Ziemann, Ferdinandus. 1910. De epistularum graecarum formulis sollemnibus quaestiones selectae. Halis Saxonum.

Zilliacus, Henrik. 1943. Zur Sprache griechischer Familienbriefe des III. Jahrhunderts n.Chr. Helsinki: Akademiska Bokhandeln. 